\title{
Probiotics in Vegetable Juices : Tomato (Solanum Lycopersicum), Carrot(Daucus Carota, Subsp. Sativus) and Beetroot Juice (Beta Vulgaris)
}

Kamila Goderska ( $\square$ kamilag@up.poznan.pl )

Poznan University of Life Sciences, Faculty of Food Technology and Nutrition, Institute of Food Technology of Plant Origin https://orcid.org/0000-0003-4724-075X

Kanan Dombhare

Poznan University of Life Sciences: Uniwersytet Przyrodniczy w Poznaniu

Elżbieta Radziejewska-Kubzdela

Poznan University of Life Sciences: Uniwersytet Przyrodniczy w Poznaniu

\section{Research Article}

Keywords: probiotics, non-dairy beverages, antioxidants, micronutrients.

Posted Date: September 29th, 2021

DOI: https://doi.org/10.21203/rs.3.rs-907042/v1

License: (c) (i) This work is licensed under a Creative Commons Attribution 4.0 International License. Read Full License 


\section{Abstract}

Twenty first century has witnessed a significant rise in the awareness regarding healthy lifestyle among the consumers and food being the important step towards a healthy life, numerous health promoting food products have gained prominent place in the food market. One such food component which is proven to have impressive health benefit is the probiotic bacteria. Probiotics are known to human kind since ages as they are important component in fermented milk products, however the use of probiotics in non-dairy product is a novel method for the delivery of probiotics. Awareness regarding health benefits of dairy products is long known to consumers but non dairy products too have good amount of micro and macronutrients and antioxidants as well which are a boon to human body. Delivery of probiotics through non-dairy products will be beneficial for consumers who are lactose intolerant who are deprived of benefits of probiotics by dairy products.

This studies aim at developing novel vegetable juices containing probiotic bacteria. Three different strains of bacteria will be used i.e. Lactobacillus plantarum, Lactobacillus acidophilus, Lactobacillus delbrueckii in carrot, beetroot and tomato juice. The viability of the bacteria will be checked after a specific duration of time of fermentation by Koch's plate count method. The vegetable used for juices (carrot, beetroot, tomato) consist of high amount of antioxidants like carotenoids in carrot, betaxanthins and betacyanins in beetroot, lycopene in tomato. These antioxidant provide numerous health benefits to human body. The antioxidant activity in the juices will be checked before and after fermentation by HPLC and spectroscopic methods. This product will be especially useful for the people who are lactose intolerant who cannot intake probiotics via milk and milk products. Vegetable juices also have almost zero fat content and high in fiber so the people who are on a fat free diet can consume this product.

\section{Introduction}

Probiotics can be defined as the live microorganisms which when consumed in adequate amount give various health benefits to the host [1].

Dairy products such as yogurt, fermented sour milk and cheese are the pioneers in probiotic dairy products. The reason dairy products are preferred for the delivery of probiotics is due the fact that the type of carrier food affect not only the viability of probiotics during processing and storage but also on their functional properties such as their proneness to adverse conditions of the gut like acidity, bile and enzymes, ability to adhere to gut epithelium and immunomodulation. The delivery of probiotics through dairy products helps them in tolerating harsh gastro intestinal conditions [2].

Apart from dairy products recently new studies have come up with the delivery of probiotics through non dairy products like fruit and vegetable juices. Fruit juices are rich in nutrients and do not contain any starter culture to compete with the probiotics therefore fruit juices are most preferred mode of delivery of probiotics. Also, the supplementation of fruit juices with oxygen scavenging ingredients such as ascorbic acid creates anaerobic conditions. High content of sugar in fruit juices also aid in the growth of probiotic 
bacteria. consumption of live probiotic bacteria confers many health benefits like controlling intestinal infections, improving lactose utilization, lowering blood ammonia and also lower serum cholesterol levels [3].

There are varied number of factors which affect the viability of the probiotics which include food parameters like $\mathrm{pH}$, titratable acidity, molecular oxygen, water activity, presence of salt, sugar and chemicals, like hydrogen peroxide, bacteriocins, artificial flavoring and coloring agents, processing parameters like heat treatment, incubation temperature, cooling rate, packaging materials and storage methods, oxygen levels, volume and microbiological parameters i.e. strains of probiotics, rate and proportion of inoculation [4]. While fruit is a suitable matrix for probiotic production, the survival of these microorganisms in such a matrix is even more complicated than in dairy products, because the lactic acid bacteria need to defend themselves from the fruit's acidic conditions [5].

Wang et al. (2009)found that noni (Morinda citrifolia) juice fermented with B. longum exhibited a higher antioxidant capacity than unfermented juice. The fermented pomegranate juice exhibited an increased antioxidant capacity, according to Mousavi et al. (2013) [6]. Some researchers have also stated that $L$. acidophilus increased juice antioxidant activity more than L. plantarum [5].

The definition of antioxidant can be stated as: "any substance that, when present in low concentrations compared to that of an oxidizable substrate, significantly delays or inhibits the oxidation of that substrate" [7]. Polyphenols are compounds that occur naturally, they are found primarily in fruits,vegetables, cereals and beverages. They occur primarily in conjugated forms, with one or more sugar residues linked to hydroxyl groups, although there are also direct connections of the sugar (polysaccharide or monosaccharide) to an aromatic carbon. It is also normal to interact with other compounds, such as carboxylic and organic acids, amines, lipids, and other phenol linkages [8]. Antioxidant activity can be effective in a variety of ways: as inhibitors of free radical oxidation reactions (preventive oxidants) by inhibiting the formation of free lipid radicals; by interrupting the propagation of the autoxidation chain reaction (chain breaking antioxidants); by quenching single oxygen; by synergism with other antioxidants; by reducing hydroperoxide converting agents; and finally as inhibitors of prooxidative enzymes (lipooxigenases) [9].

The effective antioxidant, anti-inflammatory and vascular-protective effects supplied by beetroot and its constituents have been genuinely established by means of numerous in vitro and in vivo human and animal studies; as a result, its growing reputation as a nutritional method to help manage cardiovascular ailment and cancer. In the human studies to date, beetroot supplementation has been mentioned to minimize blood pressure, attenuate inflammation, avoid oxidative stress, preserve endothelial characteristic and fix cerebrovascular haemodynamics [10]. Tomato juices can be fermented with selected species of

Lactobacillus, such as L. plantarum, L. bulgaricus, as the probiotic microorganisms, either single strain or as a mixed culture. Tomato juice fermented with lactobacilli can be developed as a potential probiotic product and may additionally benefit to consumers searching for an alternative beverage to substitute 
fermented dairy products for lactose-allergic human beings and vegetarians [11]. In carrot juices three strains of Bifidobacterium (B. lactis Bb-12, B. bifidum B7.1, and B3.2) showed considerable amount of biochemical activities in carrot juices though during fermentation $15 \%-45 \%$ of carotenoids specially acarotenoid and $\beta$-carotenoid were degraded as per the strain used [12]. Brewers yeast autolysate showed increased number of viable cells of lactic acid bacteria and enhanced production of lactic acid during fermentation of carrot and beetroot juices [13]. Lactobacillus plantarum when used as a starter culture in vegetable juices causes the production of proteolytic enzymes which soften the vegetable tissues thus increasing the juice yield [14]. Lactic acid is one of the major metabolites that is often synthesized to more than $1 \%$ in fermentation of lactic acid bacteria and also some secreted proteins and exopolysaccharides generated during food fermentation may be used as antioxidants, prevent pathogens from adhering to the intestinal mucosa, or confer immune-stimulating or hypocholesterolemic activities. Many polysaccharides also serve as prebiotics, and are fermented to short-chain fatty acids by the intestinal microbiota [15].

This study aims at developing novel vegetable juices containing probiotic bacteria. Three different strains of bacteria will be used i.e. Lactobacillus plantarum, Lactobacillus acidophilus, Lactobacillus delbrueckii in carrot, beetroot and tomato juice. The viability of the bacteria will be checked after a specific duration of time of fermentation by Koch's plate count method. The vegetable used for juices (carrot, beetroot, tomato) consist of high amount of antioxidants like carotenoids in carrot, betaxanthins and betacyanins in beetroot, lycopene in tomato. These antioxidant provide numerous health benefits to human body. The antioxidant activity in the juices will be checked before and after fermentation by HPLC and spectroscopic methods. This product will be especially useful for the people who are lactose intolerant who cannot intake probiotics via milk and milk products. Vegetable juices also have almost zero fat content and high in fiber so the people who are on a fat free diet can consume this product.

\section{Materials And Methods \\ 2.1 Materials}

Lactobacillus plantarum (Poznan University of Life Science, Department of Fermentation and Biosynthesis), Lactobacillus acidophilus (Poznan University of Life Science, Department of Fermentation and Biosynthesis), Lactobacillus delbrueckii (Poznan University of Life Science, Department of Fermentation and Biosynthesis), MRS broth (BTL, Poland), MRS agar (BTL, Poland), $0.85 \%$ sodium chloride (POCh, Poland), $1 \%$ metaphosphoric acid 5\% ditiotreithol, Acetone, Acetone for HPLC, ABTS, potassium persulphate, methanol, Trolox.

\subsection{Preparation of MRS broth and inoculum}

$100 \mathrm{ml}$ of MRS broth was prepared for inoculation of bacteria. $5.12 \mathrm{~g}$ was taken in a bottle and filled up to the volume $100 \mathrm{ml}, 10 \mathrm{ml}$ was taken in tubes and autoclaved at $121^{\circ} \mathrm{C}$ for $15 \mathrm{~min}$. After sterilization it was cooled. Strains of Lactobacillus plantarum, Lactobacillus acidophilus, Lactobacillus delbrueckii was taken from freezer and added to the MRS broth medium. The above strain was incubated at $30^{\circ} \mathrm{C}$ for $24 \mathrm{~h}$ 
and $37^{\circ} \mathrm{C}$ for $48 \mathrm{~h}$ respectively. The inoculum was centrifuged at $4000 \mathrm{rpm}(1188 \mathrm{x} \mathrm{g})$ for $10 \mathrm{~min}$, The excess broth was discarded and the bacterial culture were washed with $0.85 \% \mathrm{NaCl}, 5 \mathrm{ml}$ of $0.85 \% \mathrm{NaCl}$ is added to the culture and mixed, The bacterial culture was ready to be used in the vegetable juices.

\subsection{Preparation of juices}

Three types of juices were used in this experiment. Tomato juice, beetroot juice and carrot juice. Tomato juice was readily brought from the market which was already sterilised. Beetroot and carrot juices have been prepared in the laboratory using juicer. The later two juices were taken in a volume of $200 \mathrm{ml}$ in glass bottles. Beetroot juice has been pasteurized at $80^{\circ} \mathrm{C}$ for 10 min whereas carrot juice has been pasteurized at $70^{\circ} \mathrm{C}$ for $10 \mathrm{~min}$. Samples of fresh juices have been taken for antioxidant analysis.

\subsection{Incubation of juices}

Each type of juice had three replication of $200 \mathrm{ml}$ in glass bottles for three strains of bacteria Lactobacillus plantarum, Lactobacillus acidophilus, Lactobacillus delbrueckii. $5 \mathrm{ml}$ of inoculum of all the strains from saline solution was added to each type of juice sample. Samples with Lactobacillus plantarum were incubated for $24 \mathrm{~h}$ and $48 \mathrm{~h}$ at $30^{\circ} \mathrm{C}$ whereas samples with Lactobacillus acidophilus and Lactobacillus delbrueckii were incubated at $37^{\circ} \mathrm{C}$ for $24 \mathrm{~h}$ and $48 \mathrm{~h}$. Juice samples were taken after $24 \mathrm{~h}$ and $48 \mathrm{~h}$ for bacterial count and chemical analysis of antioxidants.

\subsection{Koch's method for total viable bacterial cells counting for juices}

The juice samples which were taken after incubation have been serial diluted in $0.85 \% \mathrm{NaCl}$ solution in 1:9 ratio. The saline solution were taken in tubes and sterilised before use. All the equipment like pipette, tubes which were used for experiments were sterilised. MRS agar has been weighed and prepared in $500 \mathrm{ml}$ bottle in $70 \%$ of the total volume of the bottle. MRS agar has been sterilised for 15 mins and was left for cooling. Petri plates have been named according to the samples. After serial dilution $1 \mathrm{ml}$ of sample has been poured on the plate using pipette and MRS agar has been added. Care was taken that the agar was not too hot. The plates were left to cool for some time then they were incubated for $48 \mathrm{~h}$. Lactobacillus plantarum has been incubated at $30^{\circ} \mathrm{C}$ while Lactobacillus acidophilus and Lactobacillus delbrueckii have been incubated at $37^{\circ} \mathrm{C}$ for $48 \mathrm{~h}$. After $48 \mathrm{~h}$ the colony forming unit has been calculated. The entire experiment has been carried out in a completely sterile condition.

\subsection{Preparation of HPLC samples for vitamin C}

$10 \mathrm{ml}$ of sample has been taken in the tubes (three replications) and $25 \mathrm{ml} 1 \%$ metaphosphoric acid has been added to it. The sample has been homogenized for $1 \mathrm{~min}$ after homogenization it has been centrifuged for $15 \mathrm{~min}$ at 5200rpm. The extract has been transferred to $50 \mathrm{ml}$ volumetric flask and made up to the volume by $1 \%$ metaphosphoric acid. $5 \mathrm{ml}$ of the prepared extract has been transferred to $10 \mathrm{ml}$ volumetric flask, $5 \% 1 \mathrm{ml}$ dithiothreitol has been added and made up the volume by $1 \%$ metaphosphoric acid. The prepared sample has been filled in the HPLC vials using filter. 


\subsection{Preparation of HPLC samples for carotenoids and lycopene}

$10 \mathrm{~g}$ of sample has been weighed into a centrifuge tube (three replications). $20 \mathrm{ml}$ of acetone has been added to each of the three tubes and homogenized for $5 \mathrm{~min}$. After homogenization it has been centrifuged for $15 \mathrm{~min}$ at $5200 \mathrm{rpm}$. The supernatant has been filtered through a filter paper using buchner funnel and transfered into the round bottom flask and evaporated. After the evaporation the extract was obtained using acetone for HPLC. The extract has been quantitatively transferred to $10 \mathrm{ml}$ volumetric flask and made up to the volume by acetone for HPLC. The extract has been filtered by $0.45 \mu \mathrm{m}$ PTFE filter and filled in HPLC vials.

\subsection{Determination of changes in the content of metabolites and sugars using high-performance liquid chromatography (HPLC)}

Preparation of the eluent

$280 \mu$ of concentrated sulphuric acid was taken into a volumetric flask and made up to $1000 \mathrm{~cm}^{3}$ with bidistilled water.

Preparation of the samples for analysis

The juice samples to measure the metabolites were diluted 10 times while the vegetable juice samples which were brought directly from the market were diluted 20 times. The samples were filtered using 0.45 $\mu \mathrm{m}$ diameter filters (Millipore, USA).

Parameters of the liquid chromatograph

- eluent: 0,005M H囚SO®,

- column temperature: $50^{\circ} \mathrm{C}$,

- flow: 0,5 ml/min,

- Phenomenex USA column for acid and sugar analysis - Rezex Polymer Based Column.

\subsection{Analysis of antioxidant activity}

ABTS solution has been prepared by dissolving ABTS in water to a $7 \mathrm{Mm}$ concentration. ABTS radical cation has been prepared by reacting ABTS stock solution with $2.45 \mathrm{Mm}$ potassium persulfate. The mixture has been allowed to stand in a dark room for 12-16 h (Re et. al., 1998). Trolox mixture was prepared by $1 \mathrm{mg} / \mathrm{ml}$ concentration in methanol. Different dilutions of $100 \mu \mathrm{g}, 150 \mu \mathrm{g}, 200 \mu \mathrm{g}, 250 \mu \mathrm{g}$, 
$300 \mu \mathrm{g}, 400 \mu \mathrm{g}$ of Trolox mixture were prepared. ABTS was diluted with methanol by 1:40 ratio. Initially the absorbance of ABTS was measured to be in the range of 0.7. Samples have been prepared from each dilution by taking $3 \mathrm{ml}$ of ABTS in tubes and adding $30 \mu \mathrm{l}$ of each dilution of Trolox. The samples have been allowed to stand in the dark for 6 mins. Absorbance has been measured immediately at $734 \mathrm{~nm}$.

$1 \mathrm{~N} \mathrm{HCl}$ has been prepared to extract antioxidants in beetroot juice. $1 \mathrm{~N} \mathrm{HCl}$ has been added to the juice

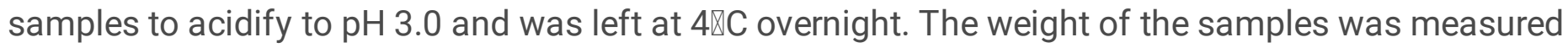
before addition. The samples have been centrifuged at $12000 \mathrm{xg}$ for $20 \mathrm{~min}$ at $4 \llbracket \mathrm{C}$. $3 \mathrm{ml}$ of ABTS solution has been taken in a tube and $30 \mu \mathrm{l}$ of supernatant from the extracted beetroot juice has been added to the tube. The solution has been allowed to stand in the dark for 6 mins. Absorbance has been measured immediately at 480 and $535 \mathrm{~nm}$ for betaxanthins and betacyanin respectively.

For measuring the antioxidant capacity of tomato and carrot juice samples of tomato and carrot juice have been weighed and have been centrifuged at $4000 \mathrm{rpm}$ for $15 \mathrm{~min}$. At first ABTS analysis has been carried out without extraction by taking $3 \mathrm{ml}$ of ABTS solution in a tube and adding $30 \mu$ l of supernatant from each sample. Absorbance has been measured at $734 \mathrm{~nm}$. For extraction $70 \%$ methanol has been prepared. Juice samples have been centrifuged and supernatant from the carrot juice has been discarded only the pellet was retained while tomato juice samples were used as it is. Sample have been prepared my adding $70 \%$ methanol twice the amount of the juice sample $\mathrm{w} / \mathrm{v}$ and have been left for overnight extraction for $12 \mathrm{~h}$ on rolling shaker. ABTS analysis has been carried out by taking $3 \mathrm{ml}$ of ABTS and adding $30 \mu \mathrm{l}$ of juice sample and were kept in dark for $6 \mathrm{~min}$. Absorbance has been measured at $734 \mathrm{~nm}$ immediately.

\section{Results And Discussion}

\subsection{Analysis of bacteria growth during juices fermentation and storage in $4^{\circ} \mathrm{C}$}

From the Fig. 1 it can be seen that the bacterial growth is quite high after $24 \mathrm{~h}$ in carrot juice compared to other two juices. However bacterial growth deceases in carrot juice after $24 \mathrm{~h}$ while it increases in tomato and beetroot juices. As observed by Panghal et al. (2017) the decrease in the amount of lactic acid bacteria is mainly due to the decrease in the amount of sugar level. As sugar level decreases due to fermentation. The Table 1 and 2 represents the colony forming unit of Lactobacillus plantarum and Lactobacillus delbrueckii respectively in three types of vegetable juices i. e tomato juice, beetroot juice and carrot juice. The results for Lactobacillus acidophilus could not be obtained as bacterial growth could not be observed on the culture plates. 
Table 1

Changes in the amount of Lactobacillus plantarum during fermentation and storage carrot, beetroot and tomato juice

\begin{tabular}{|llll|}
\hline Time (h) & $\begin{array}{l}\text { Carrot } \\
\log _{10} \mathrm{cfu} / \mathrm{ml}\end{array}$ & $\begin{array}{l}\text { Beetroot } \\
\log _{10} \mathrm{cfu} / \mathrm{ml}\end{array}$ & $\begin{array}{l}\text { Tomato } \\
\log _{10} \mathrm{cfu} / \mathrm{ml}\end{array}$ \\
\hline 0 & 7 & 7 & 7.00 \\
\hline 24 & 9.76 & 8.82 & 9.17 \\
\hline 48 & 9.27 & 9.04 & 9.23 \\
\hline $4^{\circ} \mathrm{C}$ & 9.09 & 8.04 & 8.52 \\
\hline
\end{tabular}

Table 2

Changes in the amount of Lactobacillus delbrueckii during fermentation and storage, carrot, beetroot and tomato juice

\begin{tabular}{|llll|}
\hline $\begin{array}{l}\text { Hours } \\
\text { (h) }\end{array}$ & $\begin{array}{l}\text { Tomato } \\
\log _{10} \mathrm{cfu} / \mathrm{ml}\end{array}$ & $\begin{array}{l}\text { Beetroot } \\
\log _{10} \mathrm{cfu} / \mathrm{ml}\end{array}$ & $\begin{array}{l}\text { Carrot } \\
\log _{10} \mathrm{cfu} / \mathrm{ml}\end{array}$ \\
\hline 0 & 5 & 5 & 5 \\
\hline 24 & 8.49 & 8.4 & 8.14 \\
\hline 48 & 8.46 & 8.09 & 8.19 \\
\hline $4^{\circ} \mathrm{C}$ & 8.12 & 6.54 & 0 \\
\hline
\end{tabular}

The Fig. 2 represents the growth of Lactobacillus delbrueckii in tomato, carrot and beetroot juices at the start of fermentation, $24 \mathrm{~h}, 48 \mathrm{~h}$ and storage at $4^{\circ} \mathrm{C}$.

As it is observed in tomato juice the bacterial growth gradually increases after $24 \mathrm{~h}$ and is quite constant even after refrigeration at $4^{\circ} \mathrm{C}$ so it can be said that tomato juice is optimum for lactic acid fermentation of Lactobacillus delbrueckii.

Similar to tomato juice beetroot juice also showed considerable amount of growth though after $48 \mathrm{~h}$ it decreased as in beetroot juice the sugar levels decreased which didn't provide appropriate environment for lactic acid fermentation.

In carrot juice the amount of bacteria increased and was stable up to $48 \mathrm{~h}$ however it decreased due to contamination of juice.

\subsection{Analysis of bioactive components in juices}


The Fig. 3 describes the carotenoid activity in carrot juice as it is seen the amount of $\beta$ - carotene is highest in fresh carrot juice as it is without treatment, however the amount decreases to half. The important reason for the loss could be because of the high temperature of pasteurization. Because the juice containing $L$. acidophilus and $L$. delbrueckii pasteurized at $70^{\circ} \mathrm{C}$ show stable activity compared to $L$. plantarum. So the optimum temperature for pasteurization of carrot juice is $70^{\circ} \mathrm{C}$.

On the other hand lutein and $\mathrm{a}$ - carotene show decrease in the amount after $24 \mathrm{~h}$ and $48 \mathrm{~h}$, whereas the juice containing $L$. delbrueckii show an increase in the amount of a - carotene after $48 \mathrm{~h}$ also juice with $L$. delbrueckii and $L$. acidophilus show stable activity of carotenoids. This shows that $L$. delbrueckii and $L$. acidophilus can be used as probiotics strains in carrot juice.

Table 3

The changes in the amount of carotenoids and vitamin $\mathrm{C}$ in carrot juice during $48 \mathrm{~h}$ fermentation $[\mathrm{mg} / 100 \mathrm{~g}]$

\begin{tabular}{|lllll|}
\hline Types of juices & $\begin{array}{l}\text { lutein } \pm \text { SD } \\
{[\mathrm{mg} / 100 \mathrm{~g}]}\end{array}$ & $\begin{array}{l}\boldsymbol{\beta} \text { - carotene } \pm \text { SD } \\
{[\mathrm{mg} / 100 \mathrm{~g}]}\end{array}$ & $\begin{array}{l}\text { a-carotene } \pm \text { SD } \\
{[\mathrm{mg} / 100 \mathrm{~g}]}\end{array}$ & $\begin{array}{l}\text { Vitamin C } \\
{[\mathrm{mg} / 100 \mathrm{~g}]}\end{array}$ \\
\hline Fresh juice L.p. & $0.022 \pm 0.003$ & $0.329 \pm 0.016$ & $0.164 \pm 0.009$ & 9.67 \\
\hline Fermented 24 h L.p. & $0.022 \pm 0.004$ & $0.149 \pm 0.022$ & $0.09 \pm 0.008$ & 5.9 \\
\hline Fermented 48 h L.p. & $0.015 \pm 0$ & $0.005 \pm 0.009$ & $0.08 \pm 0.005$ & 5.64 \\
\hline Fresh juice L.a & $0.016 \pm 0$ & $0.188 \pm 0.008$ & $0.09 \pm 0.006$ & 8.74 \\
\hline Fermented 24 h L.a. & $0.018 \pm 0$ & $0.17 \pm 0.008$ & $0.08 \pm 0.012$ & 9.16 \\
\hline Fermented 48 h L.a. & $0.012 \pm 0.001$ & $0.167 \pm 0.026$ & $0.081 \pm 0.011$ & 10.11 \\
\hline Fresh Juice L.d. & $0.009 \pm 0.001$ & $0.142 \pm 0.006$ & $0.047 \pm 0.011$ & 6.19 \\
\hline Fermented 24 h L.d. & $0.005 \pm 0.001$ & $0.104 \pm 0.007$ & $0.044 \pm 0.005$ & 6.58 \\
\hline Fermented 48 h L.d. & $0.004 \pm 0.001$ & $0.128 \pm 0.008$ & $0.052 \pm 0.002$ & 5.79 \\
\hline
\end{tabular}

On comparing the vitamin $\mathrm{C}$ activity in carrot juice, it has been observed that in Lactobacillus plantarum the amount of vitamin $\mathrm{C}$ is gradually decreased after $24 \mathrm{~h}$ of fermentation whereas after $24 \mathrm{~h}$ it is stable. The carrot juice with Lactobacillus plantarum was pasteurized at $80^{\circ} \mathrm{C}$, so one of the reason for the decrease in the amount of vitamin $\mathrm{C}$ could be the fact that pasteurization at high temperature causes decline in the amount of vitamin $\mathrm{C}$ content.

The juice containing Lactobacillus acidophilus show increase in the amount of vitamin C in carrot juice after $48 \mathrm{~h}$ compared to fresh juice. This is an indication that Lactobacillus acidophilus is the appropriate lactic acid bacteria for fermentation of carrot juice. On the other hand juices containing Lactobacillus delbrueckii showed a good amount of increase in juice after $24 \mathrm{~h}$ but the amount decreased after $48 \mathrm{~h}$. 
Another reason for the decrease in the amount of vitamin $\mathrm{C}$ could be that vitamin $\mathrm{C}$ is a water soluble vitamin and water soluble vitamin tend to degrade over a period of time if kept in a water medium like juices.

Overall it can be said that Lactobacillus acidophilus gives the best results for fermentation of juice containing vitamin $\mathrm{C}$ and also Lactobacillus delbrueckii if it is fermented only up to $24 \mathrm{~h}$. If we consider Lactobacillus plantarum the amount of vitamin $\mathrm{C}$ is stable after $24 \mathrm{~h}$ of fermentation i. e. if we pasteurize the juice at a lower temperature like $70^{\circ} \mathrm{C}$ like the other two juices it shall give good results as well.

In tomato juice only the juice containing Lactobacillus acidophilus and Lactobacillus delbrueckii were observed due to the lack of amount of sample of Lactobacillus plantarum it cannot be tested.

Tomato is the main source of lycopene among all the other fruits and vegetables. Fermentation do affect the amount of lycopene in the juices. As it is seen tomato juice fermented with lactic acid bacteria Lactobacillus acidophilus and Lactobacillus delbrueckii, the amount of lycopene is decreased after a period of fermentation. The fermentation is carried out between the temperature range $36^{\circ} \mathrm{C}-37^{\circ} \mathrm{C}$ and lycopene is proven to be inhibited at the temperatures above $32^{\circ} \mathrm{C}$. however comparatively the juice containing Lactobacillus delbrueckii showed better stability of lycopene than Lactobacillus acidophilus.

Lutein is the second most commonly found component in tomato juice however the quantity of lutein is very less as compared to lycopene. Lutein showed a varied activity in both the types of juices. It is observed that the amount of lutein increased after $24 \mathrm{~h}$ in both the juices and later decreased after $48 \mathrm{~h}$.

Table 4

Comparison of lutein and lycopene in tomato juice during $48 \mathrm{~h}$ fermentation

\begin{tabular}{|lll|}
\hline Types of juices & Lutein \pm SD $[\mathrm{mg} / \mathbf{1 0 0 g}]$ & Lycopene \pm SD $[\mathrm{mg} / \mathbf{1 0 0 g}]$ \\
\hline Fresh tomato juice L. a. & $0.030 \pm 0.004$ & $2.292 \pm 0.345$ \\
\hline Tomato 24 h L. $a$. & $0.061 \pm 0.022$ & $1.979 \pm 0.188$ \\
\hline Tomato 48 h L. $a$. & $0.031 \pm 0.005$ & $1.456 \pm 0.009$ \\
\hline Fresh tomato L. $d$. & $0.061 \pm 0.002$ & $1.578 \pm 0.035$ \\
\hline Tomato 24 h L. $d$. & $0.061 \pm 0.004$ & $1.446 \pm 0.003$ \\
\hline Tomato 48 h L. $d$. & $0.049 \pm 0.020$ & $1.470 \pm 0.089$ \\
\hline
\end{tabular}

\subsection{Analysis of sugars and acids in juices}


Table 5

Contents of sugars in readily available vegetable juices

\begin{tabular}{|llllll|}
\hline Sugars & $\begin{array}{l}\text { celery } \\
\text { juice }\end{array}$ & $\begin{array}{l}\text { beetroot and celery } \\
\text { juice }\end{array}$ & $\begin{array}{l}\text { cabbage } \\
\text { juice }\end{array}$ & $\begin{array}{l}\text { cucumber } \\
\text { juice }\end{array}$ & $\begin{array}{l}\text { mix vegetable } \\
\text { juice }\end{array}$ \\
\hline Maltotriose & 36.18 & 5.1 & 1.02 & 0 & 43.5 \\
\hline Fructose & 0 & 2.32 & 0 & 0 & 5.96 \\
\hline Maltose & 0 & 62.66 & 17.18 & 0.8 & 204.18 \\
\hline Sucrose & 0 & 0 & 0 & 0 & 5.3 \\
\hline Glucose & 0 & 39.78 & 0 & 0 & 126.98 \\
\hline
\end{tabular}

Table 6

Content of acids in available vegetable juices

\begin{tabular}{|llllll|}
\hline Acids & $\begin{array}{l}\text { celery } \\
\text { juice }\end{array}$ & $\begin{array}{l}\text { beetroot and celery } \\
\text { juice }\end{array}$ & $\begin{array}{l}\text { cabbage } \\
\text { juice }\end{array}$ & $\begin{array}{l}\text { cucumber } \\
\text { juice }\end{array}$ & $\begin{array}{l}\text { mix vegetable } \\
\text { juice }\end{array}$ \\
\hline Lactic acid & 3.42 & 0.2 & 0 & 1.42 & 8.08 \\
\hline Acetic acid & 1.46 & 2.48 & 3.26 & 3 & 1.66 \\
\hline $\begin{array}{l}\text { Propionic } \\
\text { acid }\end{array}$ & 1.42 & 2.18 & 1.48 & 1.48 & 2.22 \\
\hline Butyric acid & 4.94 & 5.4 & 3.32 & 5.78 & 4.2 \\
\hline $\begin{array}{l}\text { Isobutyric } \\
\text { acid }\end{array}$ & 1.36 & 0 & 3.3 & 1.82 & 1.14 \\
\hline Citric acid & 0 & 0 & 0 & 0 & 0.42 \\
\hline
\end{tabular}

If all the above juices are taken into consideration it can be seen that only juice containing beetroot and mix vegetable juice contain sugars. Other juices do not show any traces of sugar content but only acids. According to Priecina and Karklina (2015) the acids present in the vegetable juices play a very important role when it comes to processing of the juices. These acids reduce the processing time of the vegetable and vegetable based products. They also play a vital role in inhibiting the growth of sprouts that can survive temperature based treatments. The presence of acids in vegetable decreases the sterilization time as microorganisms have lower heat resistance at high acidity. Acids in combination with sugars have a higher potential during food processing and sterility.

On comparing the metabolite activity in tomato juice it was observed that the major change was in the content of glucose. In fresh tomato juice amount of glucose was considerably high but after fermentation with lactic acid bacteria the amount was gradually decreased whereas the amount of lactic acid showed 
an increase. According to El-Sayed et al. (2018) bacterial growth and organic acid production results in the changes in reducing sugars. These changes occur during $30 \mathrm{~h}$ and $48 \mathrm{~h}$ of fermentation. The selected strains of $L$. acidophillus use the sugars like fructose and glucose as a carbon source for acid production due to this reason a significant decrease in the amount of sugars is observed (Table 7 and Table 10).

Table 7

Contents of sugars in fresh vs fermented tomato juice

\begin{tabular}{|c|c|c|c|c|}
\hline Sugars & $\begin{array}{l}\text { Fresh } \\
\text { tomato } \\
\text { juice }\end{array}$ & $\begin{array}{l}\text { Fermented tomato } \\
\text { juice w/ L. plantarum }\end{array}$ & $\begin{array}{l}\text { Fermented tomato } \\
\text { juice } w / L \text {. } \\
\text { acidophillus }\end{array}$ & $\begin{array}{l}\text { Tomato juice } \\
\text { fermented } w / L \text {. } \\
\text { delbrueckii }\end{array}$ \\
\hline Fructose & 7.63 & 10.3 & 6.51 & 12.4 \\
\hline Sucrose & 0.88 & 1.6 & 0.51 & 1.14 \\
\hline Maltose & 179.9 & 83.28 & 147.86 & 161.22 \\
\hline Maltotriose & 60.35 & 36.98 & 44.29 & 45.61 \\
\hline Glucose & 104.25 & 47.8 & 0 & 0 \\
\hline
\end{tabular}

Table 10

Contents of acid in fresh vs fermented tomato juice

\begin{tabular}{|lllll|}
\hline Acids & $\begin{array}{l}\text { fresh } \\
\text { tomato } \\
\text { juice }\end{array}$ & $\begin{array}{l}\text { fermented tomato } \\
\text { juice w/ L. plantarum }\end{array}$ & $\begin{array}{l}\text { fermented tomato juice } \\
\text { w/ L. acidophillus }\end{array}$ & $\begin{array}{l}\text { tomato juice } \\
\text { fermented w/ L. } \\
\text { delbrueckii }\end{array}$ \\
\hline $\begin{array}{l}\text { Citric } \\
\text { acid }\end{array}$ & 0 & 0.63 & 0 & 0 \\
\hline $\begin{array}{l}\text { Lactic } \\
\text { acid }\end{array}$ & 10.74 & 7.83 & 8.67 & 12.4 \\
\hline $\begin{array}{l}\text { Acetic } \\
\text { acid }\end{array}$ & 0 & 0.75 & 0.4 & 0.28 \\
\hline $\begin{array}{l}\text { Propionic } \\
\text { acid }\end{array}$ & 2.71 & 2.89 & 2.65 & 3.07 \\
\hline $\begin{array}{l}\text { Butyric } \\
\text { acid }\end{array}$ & 2.64 & 2.24 & 2.44 & 2.34 \\
\hline $\begin{array}{l}\text { Isobutyric } \\
\text { acid }\end{array}$ & 0.43 & 0.54 & 0.47 & 0.54 \\
\hline
\end{tabular}

The results for metabolite activity in carrot juice show that fresh carrot juice and pasteurized carrot juice show little amount of lactic acid with fermentation with lactic acid bacteria or there is a possibility that 
since citric acid and lactic acid have similar peak values the determination couldn't been accurate (Table 8 and Table 11.). Also it is observed that the amount of citric acid and lactic acid is depleted after fermentation whereas the amount of sugars increase. According to Kun et al. (2008) who worked with fermentation of carrot juice with Bifidobacterium which show that the amount of sucrose and glucose were utilized by the bacteria as carbon source for growth while the other sugars did not show any change. Similarly in juices fermented with L. plantarum, L. acidophillus and L. delbreuckii it can be seen that the amount of fructose is decreased while other sugars is increased so it can be said that fructose is a good source of carbon for these three strains of bacteria.

Table 8

Contents of sugars in fresh vs fermented carrot juice

\begin{tabular}{|llllll|}
\hline Sugars & $\begin{array}{l}\text { Fresh } \\
\text { carrot } \\
\text { juice }\end{array}$ & $\begin{array}{l}\text { Pasteurized } \\
\text { carrot juice }\end{array}$ & $\begin{array}{l}\text { Carrot juice } \\
\text { fermented w/ L. } \\
\text { plantarum }\end{array}$ & $\begin{array}{l}\text { Carrot juice } \\
\text { fermented w/ L. } \\
\text { acidophillus }\end{array}$ & $\begin{array}{l}\text { Carrot juice } \\
\text { fermented w/ L. } \\
\text { delbrueckii }\end{array}$ \\
\hline Fructose & 23.11 & 28.48 & 19.82 & 1.32 & 0 \\
\hline Sucrose & 6.05 & 17.46 & 0.18 & 2.27 & 3.45 \\
\hline Maltose & 383.87 & 389 & 574.57 & 649.88 & 699.42 \\
\hline Maltotriose & 158.74 & 118.6 & 104.24 & 104.74 & 91.79 \\
\hline Glucose & 242.75 & 247.18 & 355.02 & 381.81 & 403.63 \\
\hline
\end{tabular}

Table 11

Contents of acid in fresh vs fermented carrot juice

\begin{tabular}{|llllll|}
\hline Acids & $\begin{array}{l}\text { Fresh } \\
\text { carrot } \\
\text { juice }\end{array}$ & $\begin{array}{l}\text { Pasteurized } \\
\text { carrot juice }\end{array}$ & $\begin{array}{l}\text { Carrot juice } \\
\text { fermented w/ L. } \\
\text { plantarum }\end{array}$ & $\begin{array}{l}\text { Carrot juice } \\
\text { fermented w/ L. } \\
\text { acidophillus }\end{array}$ & $\begin{array}{l}\text { Carrot juice } \\
\text { fermented w/ L. } \\
\text { delbrueckii }\end{array}$ \\
\hline $\begin{array}{l}\text { Citric } \\
\text { acid }\end{array}$ & 10.12 & 94.66 & 7.3 & 0 & 0 \\
$\begin{array}{l}\text { Lactic } \\
\text { acid }\end{array}$ & 7.28 & 8.38 & 0 & 0 & 0 \\
\hline $\begin{array}{l}\text { Acetic } \\
\text { acid }\end{array}$ & 1.82 & 3.07 & 0.57 & 0.27 & 0 \\
\hline $\begin{array}{l}\text { Propionic } \\
\text { acid }\end{array}$ & 0.49 & 0.52 & 1.43 & 1.62 & 0 \\
\hline $\begin{array}{l}\text { Butyric } \\
\text { acid }\end{array}$ & 1.39 & 1.51 & 1.67 & 1.97 & 0 \\
\hline $\begin{array}{l}\text { Isobutyric } \\
\text { acid }\end{array}$ & 0.72 & 0.68 & 0.39 & 0.43 & 0 \\
\hline
\end{tabular}


Table 12 Comparison of contents of acids in fresh vs fermented carrot juice

\begin{tabular}{|lllllll|}
\hline Acids & $\begin{array}{l}\text { Fresh } \\
\text { beetroot } \\
\text { juice to be } \\
\text { fermented } \\
\text { w/ L. } \\
\text { plantarum }\end{array}$ & $\begin{array}{l}\text { Beetroot } \\
\text { juice } \\
\text { fermented } \\
\text { w/ L. } \\
\text { plantarum }\end{array}$ & $\begin{array}{l}\text { Fresh } \\
\text { beetroot juice } \\
\text { to be } \\
\text { fermented w/ } \\
\text { L. }\end{array}$ & $\begin{array}{l}\text { Beetroot } \\
\text { juice } \\
\text { fermented } \\
\text { w/ L. } \\
\text { acidophillus }\end{array}$ & $\begin{array}{l}\text { Fresh } \\
\text { beetroot } \\
\text { juice to be } \\
\text { fermented } \\
\text { w/ L. } \\
\text { delbrueckii }\end{array}$ & $\begin{array}{l}\text { Fermented } \\
\text { beetroot } \\
\text { juice w/ L. } \\
\text { delbreuckii }\end{array}$ \\
\hline $\begin{array}{l}\text { Citric } \\
\text { acid }\end{array}$ & 0 & 0 & 0 & 18.62 & 8.61 & 8.05 \\
$\begin{array}{l}\text { Lactic } \\
\text { acid }\end{array}$ & 1.461 & 0 & 15.65 & 1.6 & 0 & 0 \\
\hline $\begin{array}{l}\text { Acetic } \\
\text { acid }\end{array}$ & 0.201 & 0.355 & 0 & 0.21 & 0 & 0.47 \\
\hline $\begin{array}{l}\text { Propionic } \\
\text { acid }\end{array}$ & 0.612 & 0.861 & 1.38 & 1.58 & 6.06 & 4.73 \\
\hline $\begin{array}{l}\text { Butyric } \\
\text { acid }\end{array}$ & 0.049 & 0.318 & 1.9 & 1.68 & 0 & 0 \\
\hline $\begin{array}{l}\text { Isobutyric } \\
\text { acid }\end{array}$ & 0.038 & 0.985 & 0.57 & 0.44 & 0.4 & 0.4 \\
\hline
\end{tabular}

The results for fermented beetroot show similar changes, the sugar level in the beetroot juice show decline in amount after fermentation (Table 9 and table 12). According to Panghal et al. (2017) [16] the strains of Lactobacillus rhamnnosus, Lactobacillus plantarum and Lactobacillus delbreuckii which were used to ferment beetroot juice showed a significant decline in the sugar levels as the sugars were being used as a carbon source by the bacteria.

Table 9

Contents of sugars in fresh vs fermented beetroot juice

\begin{tabular}{|lllllll|}
\hline Sugars & $\begin{array}{l}\text { Fresh } \\
\text { beetroot } \\
\text { juice to be } \\
\text { fermented } \\
\text { w/ L. } \\
\text { plantarum }\end{array}$ & $\begin{array}{l}\text { Beetroot } \\
\text { juice } \\
\text { fermented } \\
\text { w/ L. } \\
\text { plantarum }\end{array}$ & $\begin{array}{l}\text { Fresh } \\
\text { beetroot } \\
\text { juice to be } \\
\text { fermented } \\
\text { w/ L. } \\
\text { acidophillus }\end{array}$ & $\begin{array}{l}\text { Beetroot } \\
\text { juice } \\
\text { fermented } \\
\text { w/ L. } \\
\text { acidophillus }\end{array}$ & $\begin{array}{l}\text { Fresh } \\
\text { beetroot } \\
\text { juice to be } \\
\text { fermented } \\
\text { w/ L. } \\
\text { delbrueckii }\end{array}$ & $\begin{array}{l}\text { Fermented } \\
\text { beetroot } \\
\text { juice w/ } L . \\
\text { delbreuckii }\end{array}$ \\
\hline Fructose & 2.289 & 1.523 & 23.59 & 55.2 & 17.05 & 16.06 \\
\hline Sucrose & 0 & 0.044 & 2.59 & 4.19 & 5.84 & 5.98 \\
\hline Maltose & 108.873 & 88.94 & 1023.84 & 623.22 & 967.92 & 797.47 \\
\hline Maltotriose & 18.048 & 14.597 & 162.78 & 68.33 & 145.97 & 122.75 \\
\hline Glucose & 62.962 & 51.604 & 593.23 & 360.03 & 554.29 & 453.16 \\
\hline
\end{tabular}




\subsection{Results for ABTS analysis}

The Figs. 14 give the information about the antioxidant activity of betaxanthins and betacyanins in fermented beetroot juice. According to Panghal et al. (2017) [16] the fermented beetroot juice showed an increase in the antioxidant activity by $3 \%$ due to microbial hydrolysis reaction which lead to an increase in phenols and flavonoids. In the Fig. 14. the activity of betaxanthin do not show positive results as the is a decrease in activity after fermentation. We can say that fermentation is not favorable for this compound. On the contrary if Fig. 15. is observed which shows the activity for betacyanin, the activity is increased after fermentation. This indicates that fermentation is good for this component. Also according to Panghal et al., (2017) [16] fermentation results in the structural disintegration of cell wall which results in the synthesis of different antioxidants. Antioxidants posses free radical scavenging capacity they have good health benefits so this probiotic drink is beneficial.

Table 13

Antioxidant activity in beetroot juice

\begin{tabular}{|lll|}
\hline Types of Juice & $\begin{array}{l}\text { Betaxanthin in beetroot at } \mathbf{4 8 0} \mathbf{~ n m ~ [ T E ~} \\
\mathbf{m g} / \mathbf{1 0 0 g}]\end{array}$ & $\begin{array}{l}\text { Betacyanin in beetroot at } \\
\mathbf{5 3 5} \mathbf{~ n m} \\
\text { [TE } \mathbf{~ m g / 1 0 0 g ]}\end{array}$ \\
\hline ABTS & 0 & 0 \\
\hline Fresh beet juice L.plantarum & 14.747 & 30.41333 \\
\hline $\begin{array}{l}\text { Fermented beet juice } \\
\text { L.plantarum }\end{array}$ & 17.213 & 26.54667 \\
$\begin{array}{l}\text { Fresh beet juice } \\
\text { L.acidophilus }\end{array}$ & 11.613 & 24.94667 \\
\hline $\begin{array}{l}\text { Fermented beet juice } \\
\text { L.acidophilus. }\end{array}$ & 31.88 & 19.48 \\
\hline $\begin{array}{l}\text { Fresh beet juice } L . \\
\text { delbrueckii. }\end{array}$ & 31.347 & 43.48 \\
$\begin{array}{l}\text { Fermented beet juice } L . \\
\text { delbrueckii }\end{array}$ & 35.48 & 45.68 \\
\hline
\end{tabular}

The Figs. 15 show the antioxidant activity in carrot juice before and after extraction a rise in the antioxidant activity can be seen after fermentation. As discussed earlier the antioxidant activity increases after fermentation. However after pasteurization process the activity decreases it might be due to heat processing which affect the antioxidant activity however it increases after fermentation. 
Table 14

Antioxidant activity in carrot juice

\begin{tabular}{|lll|}
\hline Types of Juice & $\begin{array}{l}\text { Antioxidant activity without extraction } \\
{[\text { TE } \mathbf{~ m g / 1 0 0 g ]}}\end{array}$ & $\begin{array}{l}\text { Antioxidant activity with extraction } \\
\text { [TE mg/100g] }\end{array}$ \\
\hline ABTS & 0 & 0 \\
\hline Fresh carrot juice & 33.68 & 12.14667 \\
\hline $\begin{array}{l}\text { Pasteurized carrot } \\
\text { juice }\end{array}$ & 39.08 & 19.61333 \\
\hline $\begin{array}{l}\text { Fermented with } \\
\text { L.plantarum }\end{array}$ & 15.14667 & 7.613333 \\
$\begin{array}{l}\text { Fermented with } \\
\text { L.acidophilus }\end{array}$ & 8.613333 & 4.88 \\
$\begin{array}{l}\text { Fermented with L. } \\
\text { delbrueckii }\end{array}$ & 0 & 3.546667 \\
\hline
\end{tabular}

The Figs. 16 shows the antioxidant activity in tomato juice before and after extraction and the results show that the antioxidant activity is better in the juice without extraction. There is a loss of antioxidants after extraction process this can be due to the chemicals used for extraction which caused the loss. Because the antioxidant activity in the Fig. 16 increase after fermentation which is positive.

Table 15

Antioxidant activity in tomato juice before and after extraction with $70 \%$ Methanol

\begin{tabular}{|lll|}
\hline Types of Juices & $\begin{array}{l}\text { Antioxidant activity without extraction } \\
{[\mathrm{TE} \mathbf{~ m g} / \mathbf{1 0 0 g}]}\end{array}$ & $\begin{array}{l}\text { Antioxidant activity after extraction } \\
{[\mathrm{TE} \mathbf{~ m g} / \mathbf{1 0 0 g}]}\end{array}$ \\
\hline ABTS & 0 & 0 \\
\hline Fresh tomato juice & 31.74667 & 11.61333 \\
\hline $\begin{array}{l}\text { Fermented with } \\
\text { L.plantarum }\end{array}$ & 24.74667 & 9.746667 \\
\hline $\begin{array}{l}\text { Fermented with } \\
\text { L.acidophilus }\end{array}$ & 23.28 & 11.01333 \\
$\begin{array}{l}\text { Fermented with L. } \\
\text { delbrueckii }\end{array}$ & 19.08 & 11.81333 \\
\hline
\end{tabular}


Table 19

Correlation between carotenoids in carrot juice detected through HPLC and ABTS methods (without extraction)

\begin{tabular}{|llll|}
\hline Type of juice & Carotenoids & ABTS & Correlation co-efficient \\
\cline { 1 - 3 } Fresh carrot juice & 0.515 & 33.68 & \multirow{2}{*}{0.932189} \\
\cline { 1 - 3 } Fermented with L.plantarum & 0.240 & 15.14667 & \\
\cline { 1 - 3 } Fermented with L.acidophilus & 0.26 & 8.613333 & \\
\cline { 1 - 3 } Fermented with L. delbrueckii & 0.183997 & 0 & \\
\hline
\end{tabular}

Table 20

Correlation between carotenoids in carrot juice detected through HPLC and ABTS methods (after extraction)

\begin{tabular}{|llll|}
\hline Type of juice & Carotenoids & ABTS & Correlation co-efficient \\
\cline { 1 - 3 } Fresh carrot juice & 0.515 & 12.14667 & 0.927793 \\
\cline { 1 - 3 } Fermented with L.plantarum & 0.240 & 7.613333 & \\
\cline { 1 - 3 } Fermented with L.acidophilus & 0.26 & 4.88 & \\
\cline { 1 - 3 } Fermented with L. delbrueckii & 0.183997 & 3.546667 & \\
\hline
\end{tabular}

Table 21

Correlation between total antioxidants in tomato juice detected through HPLC and ABTS methods (without extraction)

\begin{tabular}{|c|c|c|c|}
\hline Type of juice & Total antioxidants & ABTS & Correlation coefficient \\
\hline Fresh tomato juice & 2.35 & 31.74667 & 0.864292 \\
\hline Fermented with L.plantarum & 2.07 & 24.74667 & \\
\hline Fermented with L.acidophilus & 1.55 & 23.28 & \\
\hline
\end{tabular}


Table 22

Correlation between total antioxidants in tomato juice detected through HPLC and ABTS methods (after extraction)

\begin{tabular}{|llll|}
\hline Type of juice & Total antioxidants & ABTS & Correlation coefficient \\
\hline Fresh tomato juice & 2.35 & 11.61333 & \multirow{2}{*}{0.153396} \\
\cline { 1 - 3 } Fermented with L.plantarum & 2.07 & 9.746667 & \\
\cline { 1 - 3 } Fermented with L.acidophilus & 1.55 & 11.01333 & \\
\hline
\end{tabular}

\subsection{Comparison of different bacterial strains in juices}

The Fig. 17 shows the activity of different strains of bacteria in carrot juice and it can be seen that the strain of $L$. plantarum has a steady growth till $24 \mathrm{~h}$ and it declines after $48 \mathrm{~h}$ and is stable at $4^{\circ} \mathrm{C}$ while $L$. delbreuckii shows a good growth up to $48 \mathrm{~h}$. The decrease in the amount of $L$. delbreuckii at $4^{\circ} \mathrm{C}$ can be due to contamination of the juice. Overall on comparing both the bacterial strains it can be said that both the strains are suitable for fermentation of carrot juice if there is no contamination.

Table 16

Changes of the growth of L. plantarum and

L. delbreauckii in carrot juice at different intervals of time

\begin{tabular}{|lll|}
\hline Time [h] & L. plantarum & L. delbreuckii \\
\hline 0 & 7 & 5 \\
24 & 9.76 & 8.14 \\
48 & 9.27 & 8.19 \\
$4^{\circ} \mathrm{C}$ & 9.09 & 0 \\
\hline
\end{tabular}

The Fig. 18 shows the activity of different strains of bacteria in tomato juice and it can be seen that the strain of $L$. plantarum has a steady growth till $24 \mathrm{~h}$ and it declines after $48 \mathrm{~h}$ and is stable at $4^{\circ} \mathrm{C}$ while $L$. delbreuckii shows a good growth up to $48 \mathrm{~h}$. The decrease in the amount of $L$. delbreuckii at $4^{\circ} \mathrm{C}$ can be due to contamination of the juice. Overall on comparing both the bacterial strains it can be said that both the strains are suitable for fermentation of carrot juice if there is no contamination. 
Table 17

Changes of the growth of L. plantarum and

L. delbreuckii in tomato juice at different intervals of time

\begin{tabular}{|lll|}
\hline Time [h] & L. plantarum & L. delbreuckii \\
\hline 0 & 7.00 & 5 \\
\hline 24 & 9.17 & 8.49 \\
\hline 48 & 9.23 & 8.46 \\
\hline $4^{\circ} \mathrm{C}$ & 8.52 & 8.12 \\
\hline
\end{tabular}

The Fig. 19 compares the growth of L. plantarum and L. delbreuckii in beetroot juice.From the figure it can be seen that $L$. plantarum show positive growth up to $48 \mathrm{~h}$ whereas $L$. delbreuckii showed good growth only up to $24 \mathrm{~h}$ and decreased after $48 \mathrm{~h}$ which says that for beetroot juice $L$. plantarum is more suitable for fermentation of beetroot juice than L. delbreuckii. Both the juice show decline after cold storage so similar to tomato juice, beetroot juice also cannot be stored for long at $4^{\circ} \mathrm{C}$ to maintain the viability of the bacteria.

Table 18

Changes of the growth of L. plantarum and

L. delbreuckii in beetroot juice at different intervals of time

\begin{tabular}{|lll|}
\hline Time [h] & L. plantarum & L. delbreuckii \\
\hline 0 & 7 & 5 \\
24 & 8.82 & 8.4 \\
48 & 9.04 & 8.09 \\
$4^{\circ} \mathrm{C}$ & 8.04 & 6.54 \\
\hline
\end{tabular}

\section{Conclusions}

The three bacterial strains Lactobacillus plantarum, Lactobacillus acidophilus and Lactobacillus delbrueckii used in three types of juices tomato juice, carrot juice and beetroot juice showed good growth except Lactobacillus acidophilus due to reasons like insufficient nutrients and contamination. Among the other two strains Lactobacillus plantarum and Lactobacillus delbrueckii, Lactobacillus plantarum showed consistent positive growth in all the three types of juices. So the most suitable bacterial strain for fermenting vegetable juices was Lactobacillus plantarum. 
The amount of carotenoids in carrot juice have decreased after fermentation which is not positive but they are not depleted completely and show satisfying amount. On the other hand there is an increase in the amount of vitamin $\mathrm{C}$ which is a good indicator as vitamin $\mathrm{C}$ acts as an immunity booster.

The amount of sugars and acids of the three juices indicated that the fermentation process takes place at a good and satisfying rate. As the consumption of sugars show a positive activity in the juices. Similarly for antioxidant activity, the increase in amount of antioxidant in the juices show that along with the benefits provided by the lactic acid bacteria antioxidant also play an important role in providing health benefits.

The overall conclusion can be said that like traditionally used probiotic dairy products, the nondairy products with probiotic properties have tremendous potential of highly nutritious health drink providing additional health benefits which can not be found in some dairy products. This product can be used by all the groups specially who are lactose intolerant.

\section{Declarations}

\section{Funding}

Not applicable

\section{Conflicts of interest/Competing interests}

The authors declare that they have no conflict of interest

\section{Availability of data and material}

All data generated or analysed during this study are included in this published article (and its supplementary information files).

\section{Code availability}

Not applicable

\section{Authors' contributions}

All authors contributed to the study conception and design. Material preparation, data collection and analysis were performed by [Kamila Goderska], [Kanan Dombhare] and [Elżbieta Radziejewska-Kubzdela]. The first draft of the manuscript was written by [Kamila Goderska] and all authors commented on previous versions of the manuscript. All authors read and approved the final manuscript.

\section{Ethics approval}

This article does not contain any studies with human participants performed or animals by any of the authors. 


\section{Consent to participate}

Not applicable

\section{Consent for publication}

I agree to the publication of.

\section{References}

[1] Butel, M.J. (2013) Médecine et Maladies Infectieuses,1-8.

[2] Ranadheera, C.S., Vidanarachchi, J.K., Rocha, R.S., Cruz, A.G., Ajlouni, S. (2017) Fermentation, 3(67), 117.

[3] Ding, W.K., Shah, N.P. (2008) Inter. Food Res. J., 15(2), 219-232.

[4] Perricone, M., Bevilacqua, A., Altieri, C., Sinigaglia, M., Rosaria Corbo, M. (2015) Beverages, 1020095.

[5] Fernandes Pereira, A.L., Rodrigues, S. (2018) Fruit Juices,279-287.

[6] Mousavi, Z.E., Mousavi, S.M., Razavi, S.H., Hadinejad, M., Emam-Djomeh, Z., Mirzapour, M. (2013) Food Biotechnol., 27(1), 1-13.

[7] Halliwell, B., Gutteridge, J.C. (1995) Free Radic. Biol. Med., 18, 125-6.

[8] Pandey, K.B., Rizvi, S.I. (2009) Oxidative Med. Cel. Longevity 2(5),270-278.

[9] Carocho, M., Ferreira, I.C.F.R. (2013) Food Chem. Toxicol., 51, 15-25.

[10] Clifford, T., Howatson, G., West, D.J., Stevenson, E.J. (2015)Nutrients, 7, 2801-2822.

[11] El- Sayed AA, Rabie MA, El-Maaty SMA, El- Nemr SEA (2018) Carpat J Food Sci Technol, 9-10.

[12] Kun, S., Rezessy-Szabo, J.M., Nguyen, Q.D., Hoschke, A. (2008) Process Biochem., 818-820.

[13] Rakin, M., Vukasinovic, M., Siler-Marinkovic, S., Maksimovic, M. (2005) Food Chem., 100 (2007), 599602.

[14] Demir, N., Bahçeci, K.S., Acar, J. (2006) J. Food Proces. Preserv., 30, 352-363.

[15] Devaki, C.S., Premavalli, K.S. (2019) Fermented Beverages, 334-335.

[16] Panghal, A., Virkar, K., Kumar, V., Dhull, S.B., Gat, Y., Chhikara, N. (2017) Cur. Res. Nutr. Food Sci., 5(3), 257-262. 
Figures

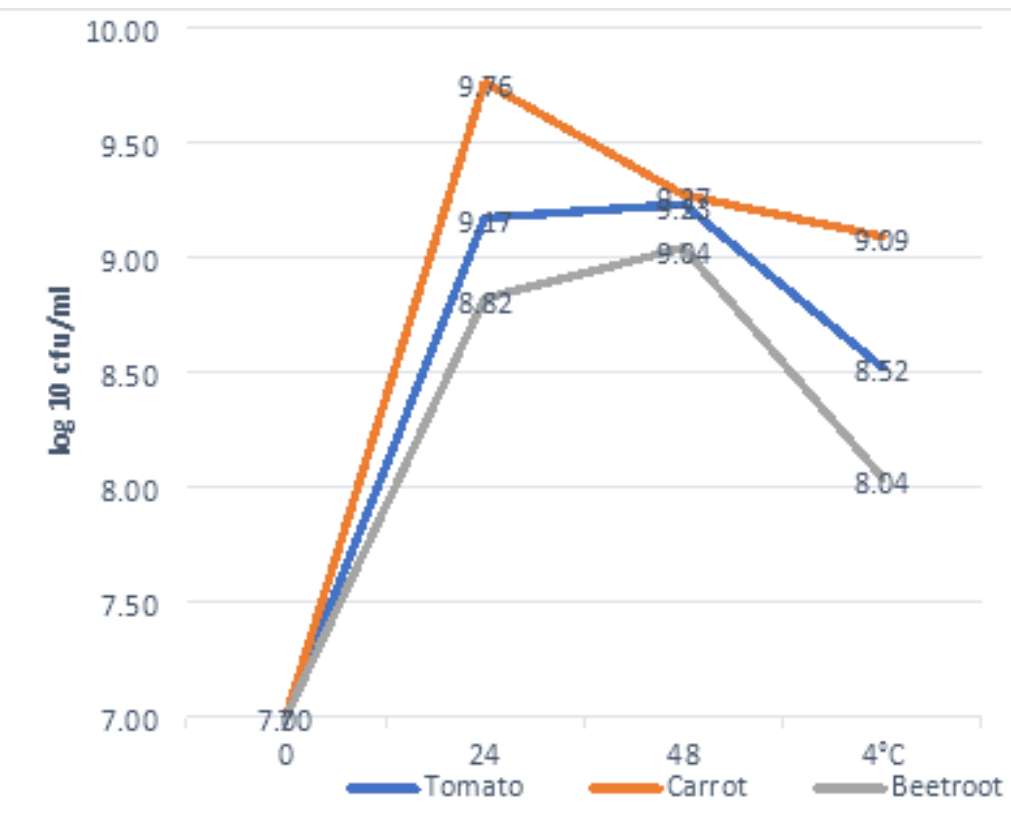

\section{Figure 1}

Comparison changes in the amount of Lactobacillus plantarum during fermentation and storage in $4^{\circ} \mathrm{C}$ three types of juices

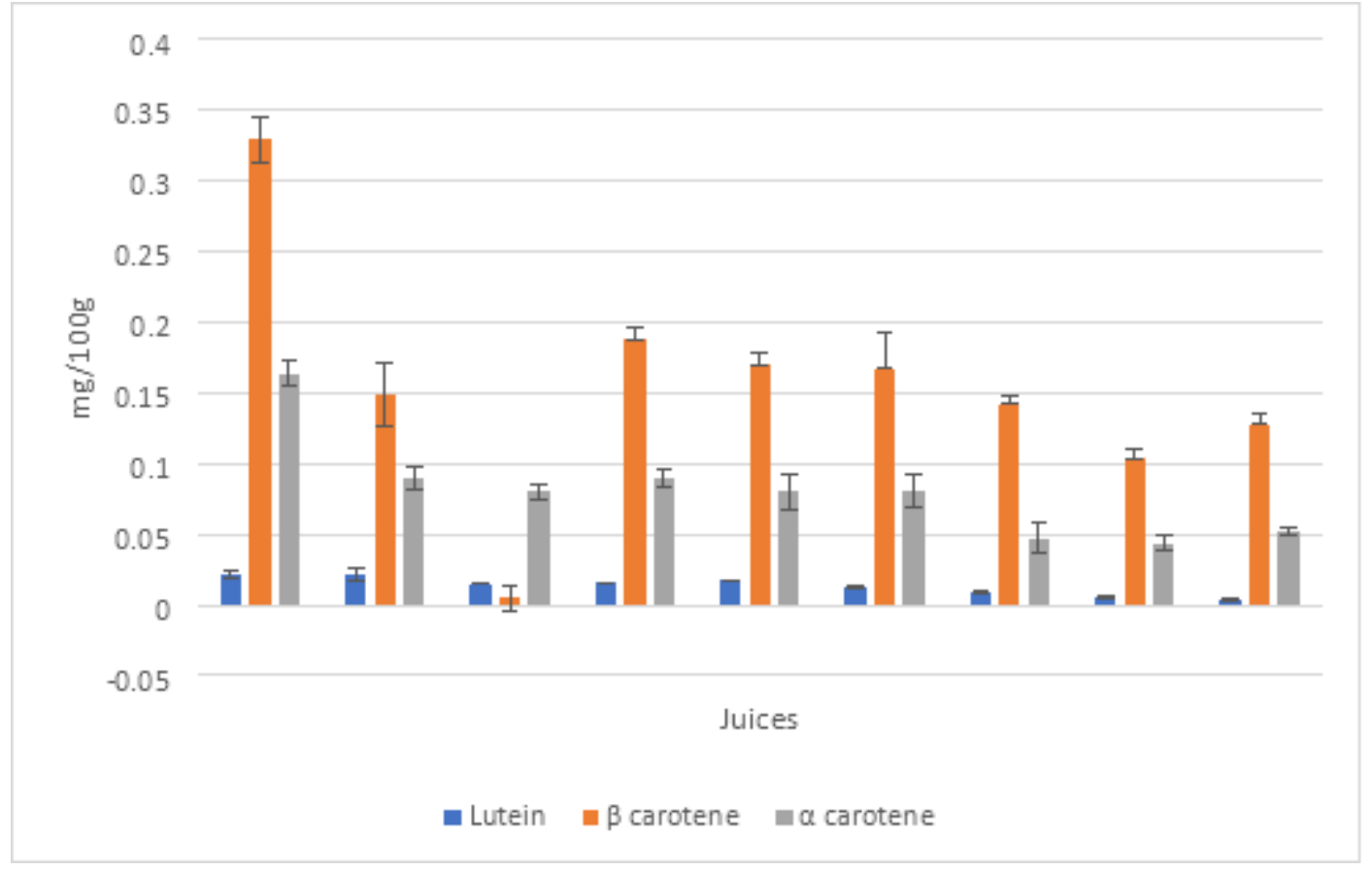

\section{Figure 3}

Comparison of carotenoids activity in carrot juice during $48 \mathrm{~h}$ fermentation (1.Fresh juice 2. Juice fermented with Lactobacillus plantarum for $24 \mathrm{~h} 3$. Juice fermented with Lactobacillus plantarum for $48 \mathrm{~h}$ 4. Fresh Juice 5. Juice fermented with Lactobacillus acidophillus for $24 \mathrm{~h} 6$. Juice fermented with 
Lactobacillus acidophillus for $48 \mathrm{~h} 7$. Fresh juice 8. Juice fermented with Lactobacillus delbreuckii for 24h, 9. Fresh juice 8. Juice fermented with Lactobacillus delbreuckii for 48h ).

\section{Vitamin C}

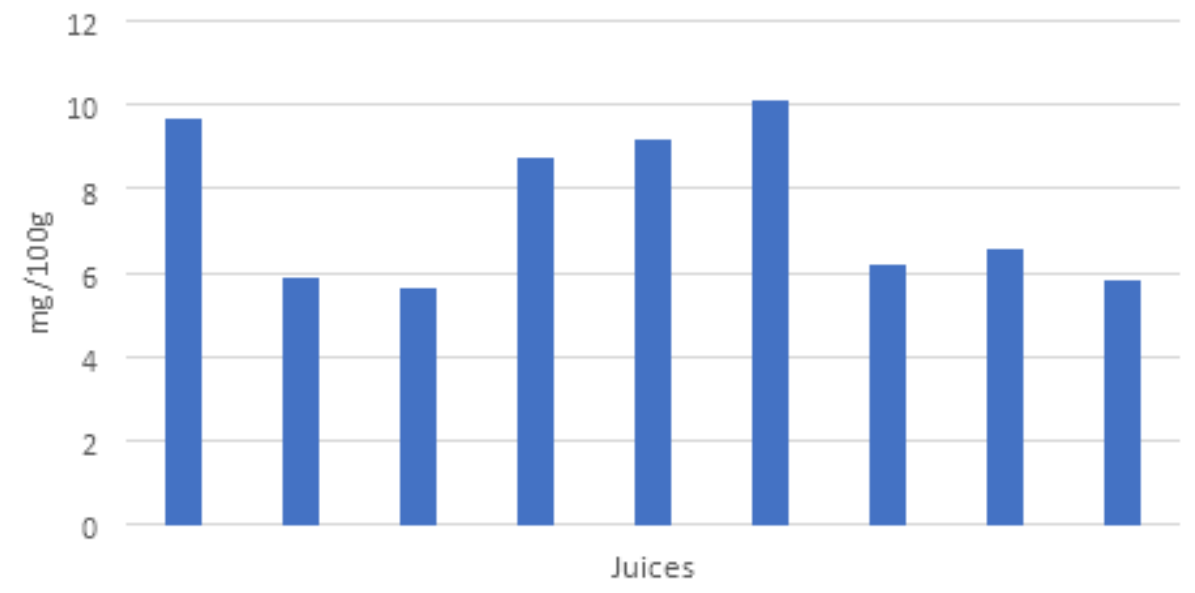

\section{Figure 4}

Comparison of Vitamin $\mathrm{C}$ in carrot juice during $48 \mathrm{~h}$ fermentation with different strains of lactic acid bacteria (1. Fresh juice 2. Juice fermented with Lactobacillus plantarum for $24 \mathrm{~h} 3$. Juice fermented with Lactobacillus plantarum for $48 \mathrm{~h} 4$. Fresh Juice 5 . Juice fermented with Lactobacillus acidophillus for $24 \mathrm{~h}$ 6. Juice fermented with Lactobacillus acidophillus for $48 \mathrm{~h} 7$. Fresh juice 8 . Juice fermented with Lactobacillus delbreuckii for $24 \mathrm{~h} 9$. Fresh juice 8 . Juice fermented with Lactobacillus delbreuckii for $48 \mathrm{~h}$ ) .

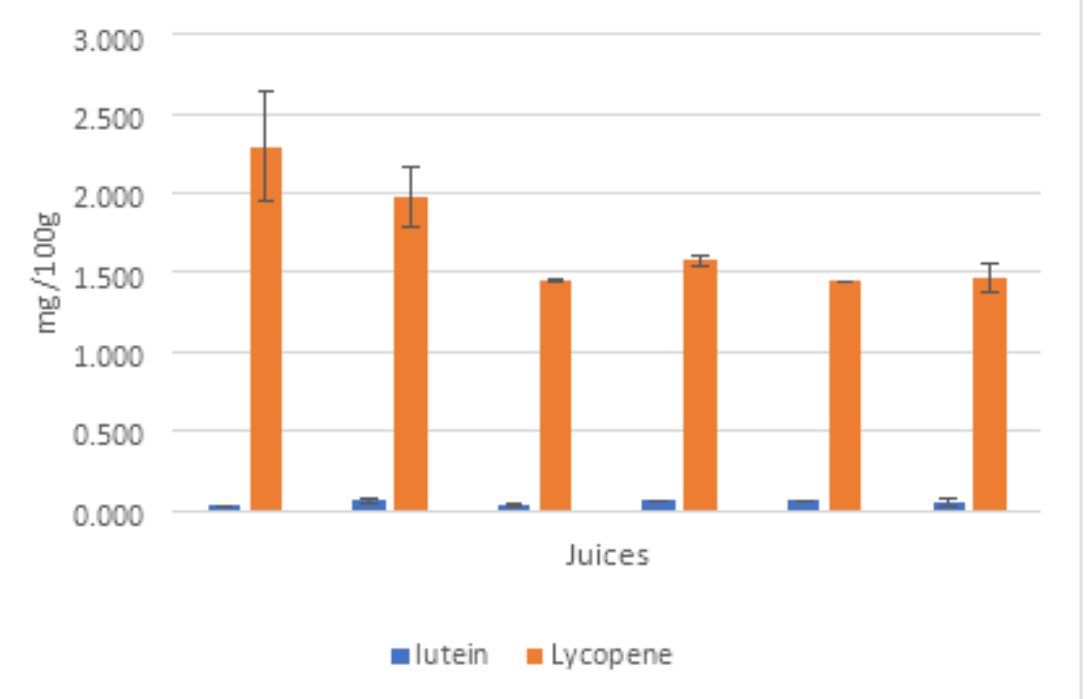

Figure 5

Comparison of the most abundantly found components lutein and lycopene in tomato juice during $48 \mathrm{~h}$ fermentation with different strains of lactic acid bacteria (1. Fresh tomato juice to be fermented with Lactobacillus acidophillus 2. Tomato juice fermented with Lactobacillus acidophillus for $24 \mathrm{~h} 3$. Tomato 
juice fermented with Lactobacillus acidophillus for $48 \mathrm{~h} 4$. Fresh tomato juice to be fermented with Lactobacillus delbreuckii 5 . Tomato juice fermented with Lactobacillus delbreuckii for $24 \mathrm{~h} 6$. Tomato juice fermented with Lactobacillus delbreuckii for $48 \mathrm{~h}$.

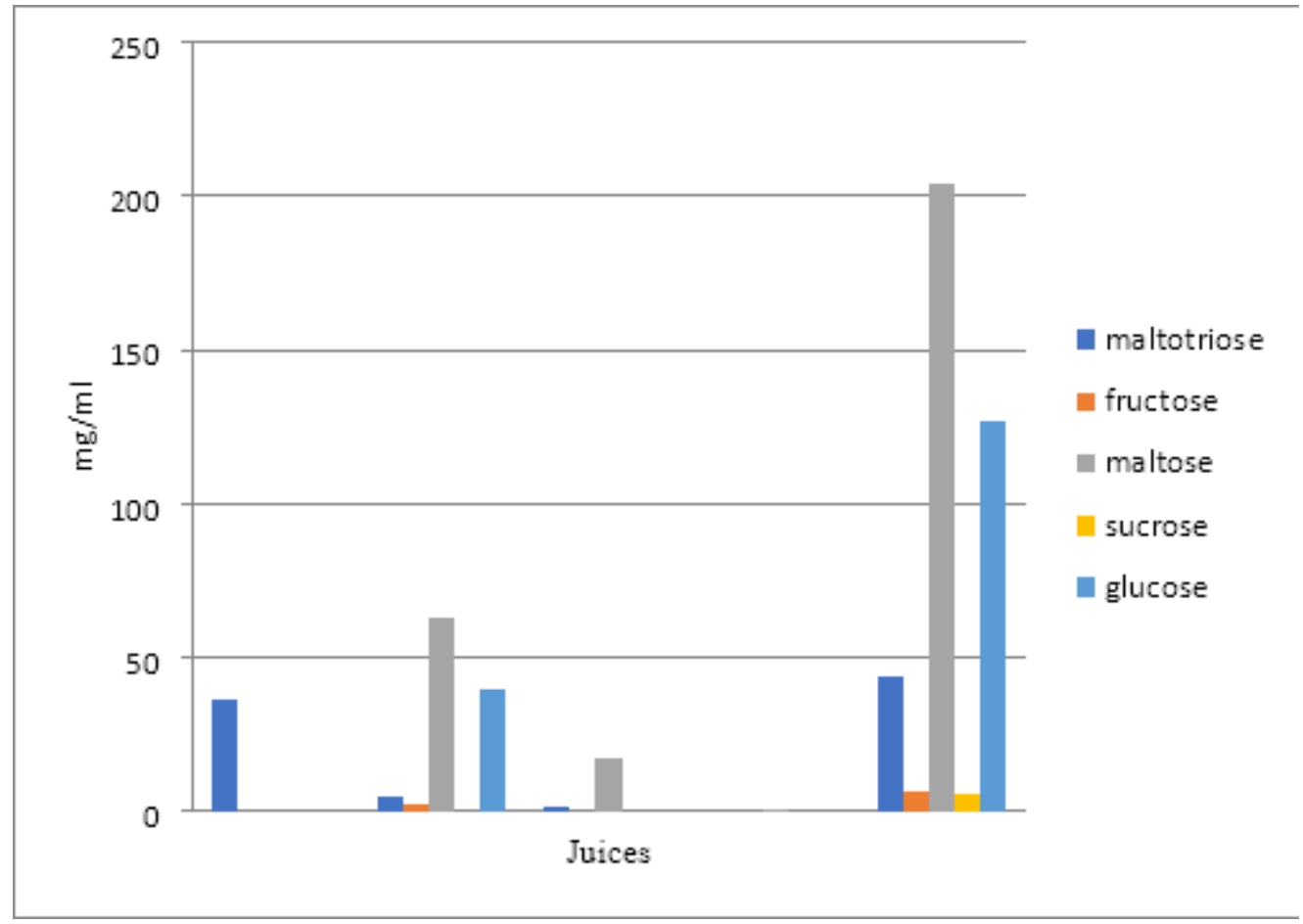

Figure 6

comparison of sugars in available vegetable juices (1. Celery juice 2. Beetroot and celery juice 3. Cabbage juice 4. Cucumber juice 5. Mix vegetable juice)

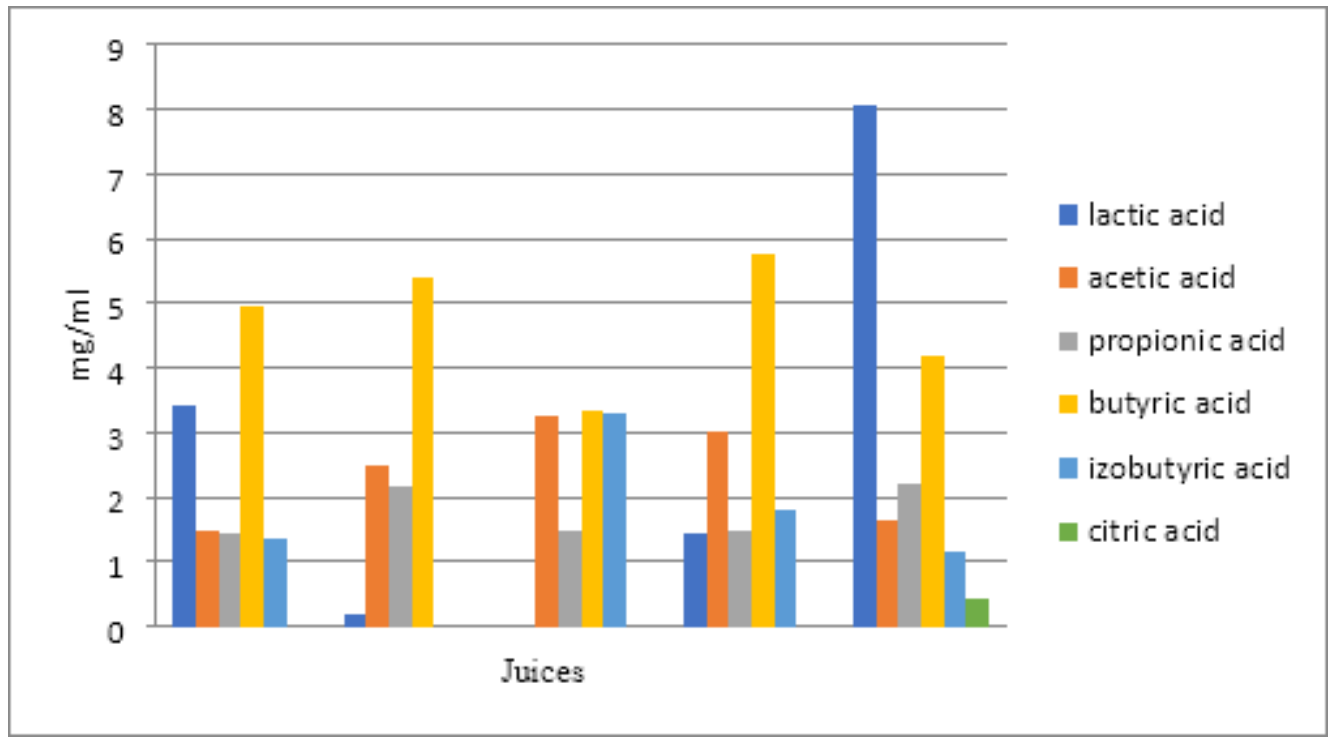

\section{Figure 7}

comparison of acids in available vegetable juices (1. Celery juice 2. Beetroot and celery juice 3. Cabbage juice 4. Cucumber juice 5. Mix vegetable juice) 


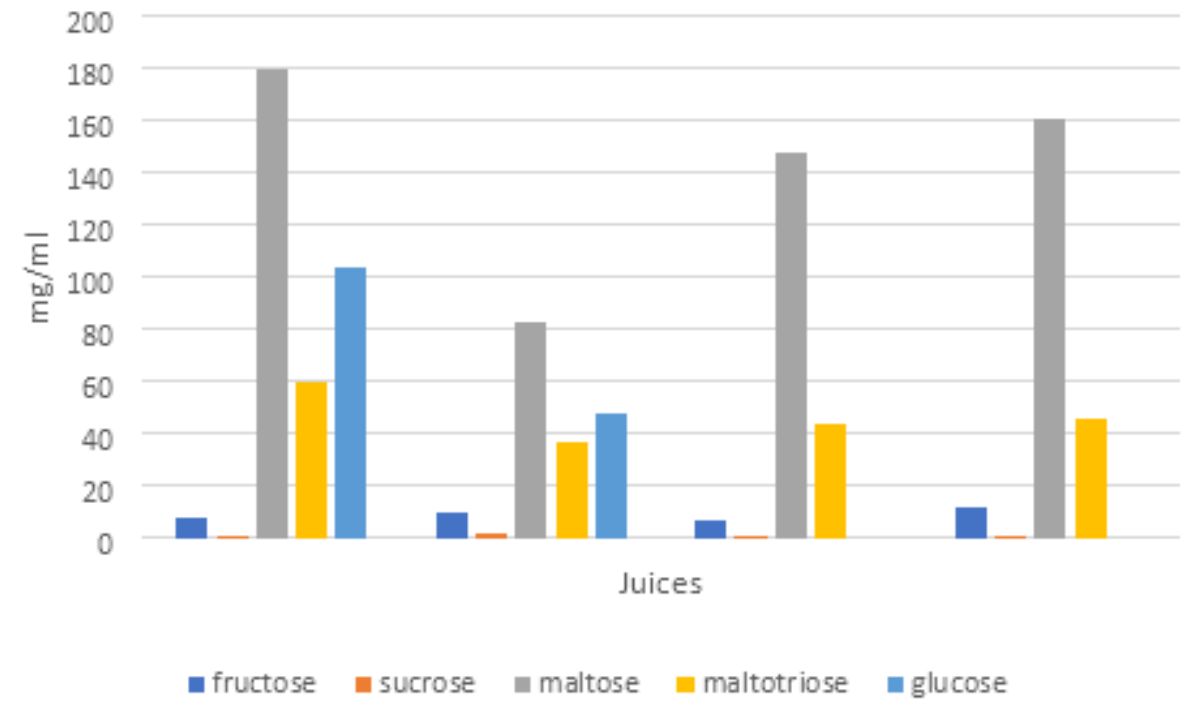

Figure 8

Comparison of contents of sugar in fresh vs fermented tomato juice (1. Fresh tomato juice 2. Fermented tomato juice with Lactobacillus plantarum 3. Fermented tomato juice with Lactobacillus acidophillus 4. Fermented tomato juice with Lactobacillus delbrueckii ).

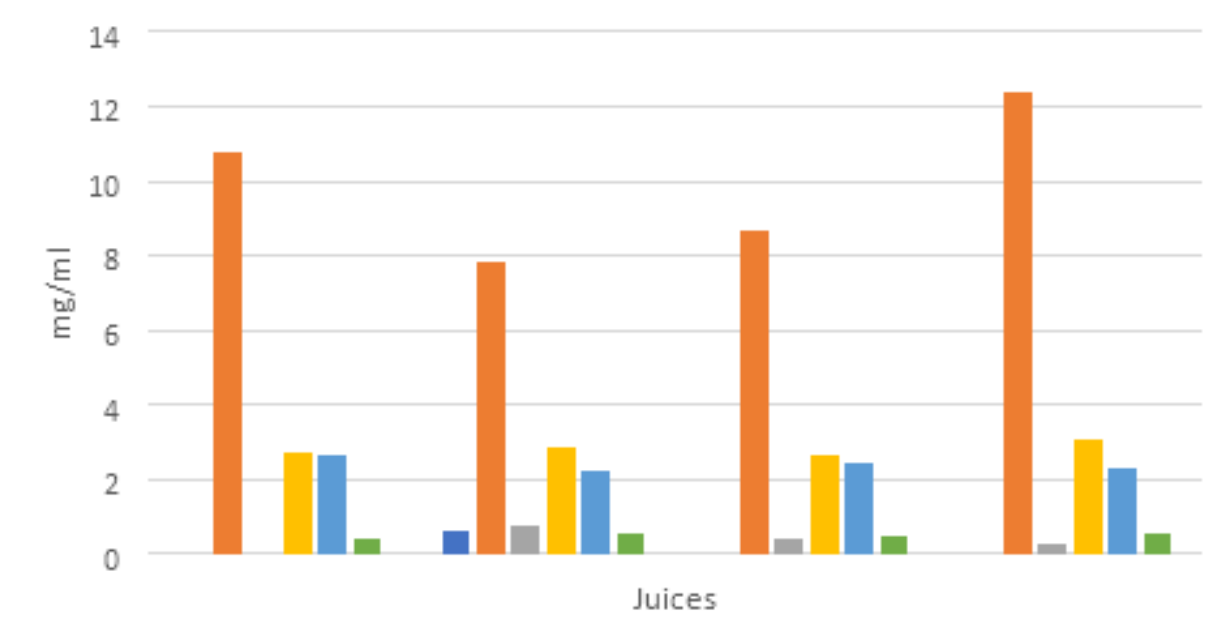

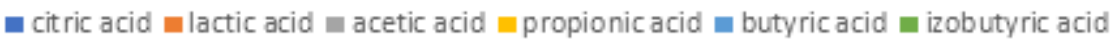

\section{Figure 9}

Comparison of contents of acids in fresh vs fermented tomato juice (1. Fresh tomato juice 2. Fermented tomato juice with Lactobacillus plantarum 3. Fermented tomato juice with Lactobacillus acidophillus 4. Fermented tomato juice with Lactobacillus delbrueckii ). 


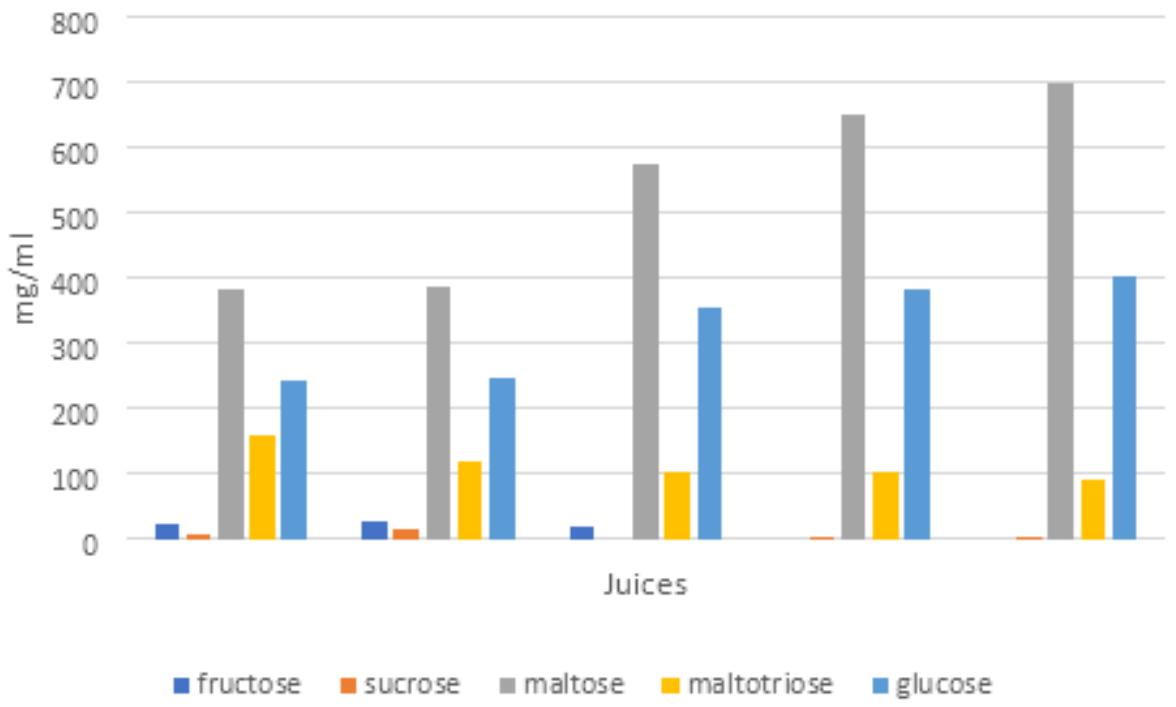

Figure 10

Comparison of contents of sugar in fresh vs fermented carrot juice (1. Fresh carrot juice 2. Pasteurized carrot juice 3. Carrot juice fermented with Lactobacillus plantarum 4. Carrot juice fermented with Lactobacillus acidophillus 5. Carrot juice fermented with Lactobacillus delbrueckii)



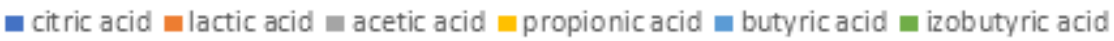

\section{Figure 11}

Comparison of contents of acids in fresh vs fermented carrot juice (1. Fresh carrot juice 2. Pasteurized carrot juice 3. Carrot juice fermented with Lactobacillus plantarum 4. Carrot juice fermented with Lactobacillus acidophillus 5. Carrot juice fermented with Lactobacillus delbrueckii) 


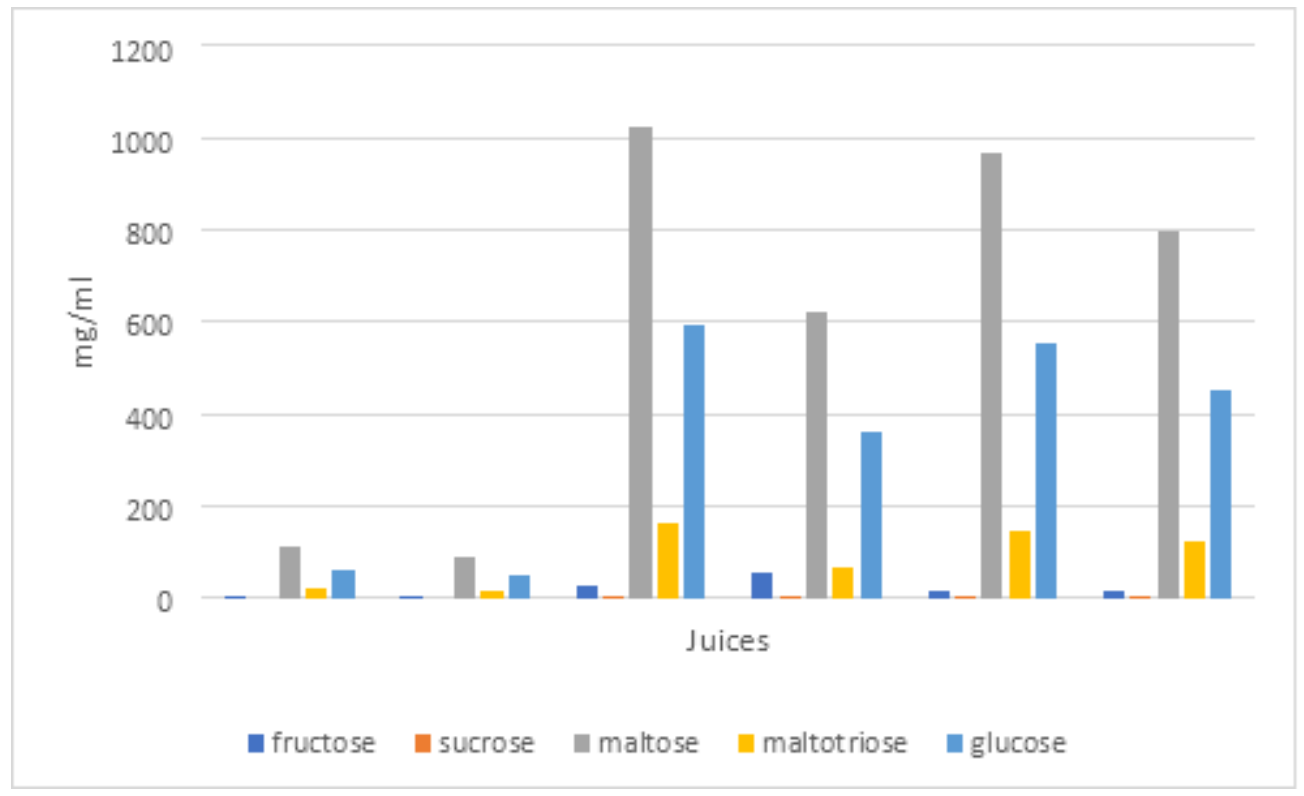

Figure 12

Comparison of contents of sugar in fresh vs fermented beetroot juice (1. Fresh beetroot juice to be fermented with Lactobacillus plantarum 2. Beetroot juice fermented with Lactobacillus plantarum 3. Fresh beetroot juice to be fermented with Lactobacillus acidophillus 4 . Beetroot juice fermented with Lactobacillus acidophillus 5. Fresh beetroot juice to be fermented with Lactobacillus delbreuckii 6 . Beetroot juice fermented with Lactobacillus delbreuckii)

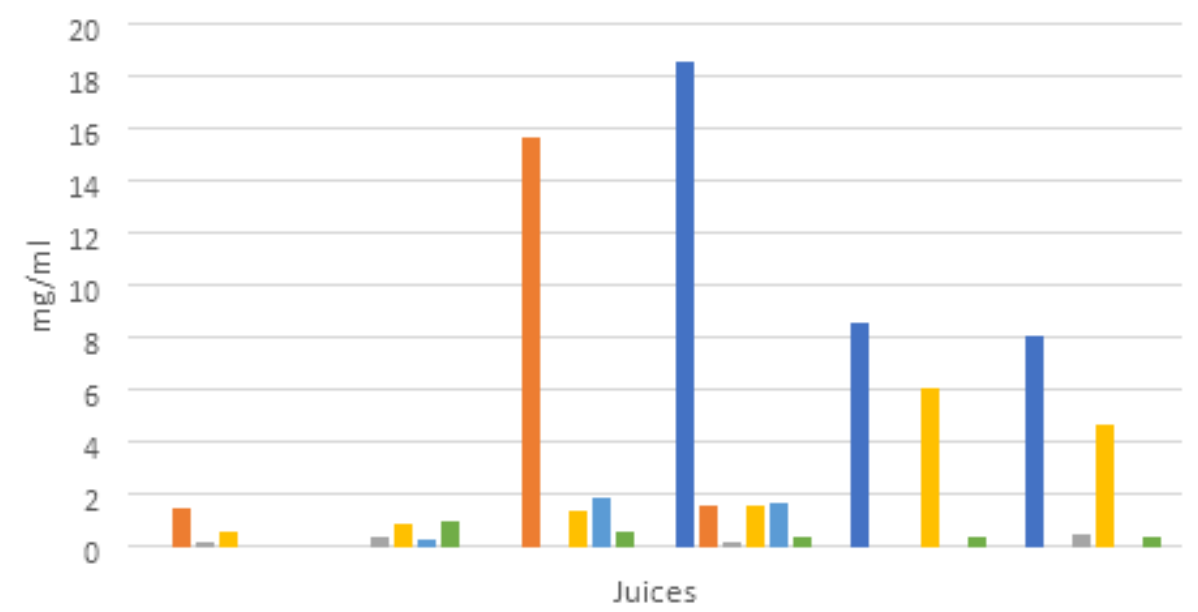

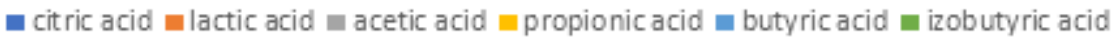

\section{Figure 13}

Comparison of contents of acids in fresh vs fermented beetroot juice (1.Fresh beetroot juice to be fermented with Lactobacillus plantarum 2. Beetroot juice fermented with Lactobacillus plantarum 3. Fresh beetroot juice to be fermented with Lactobacillus acidophillus 4 . Beetroot juice fermented with Lactobacillus acidophillus 5. Fresh beetroot juice to be fermented with Lactobacillus delbreuckii 6 . Beetroot juice fermented with Lactobacillus delbreuckii ) 


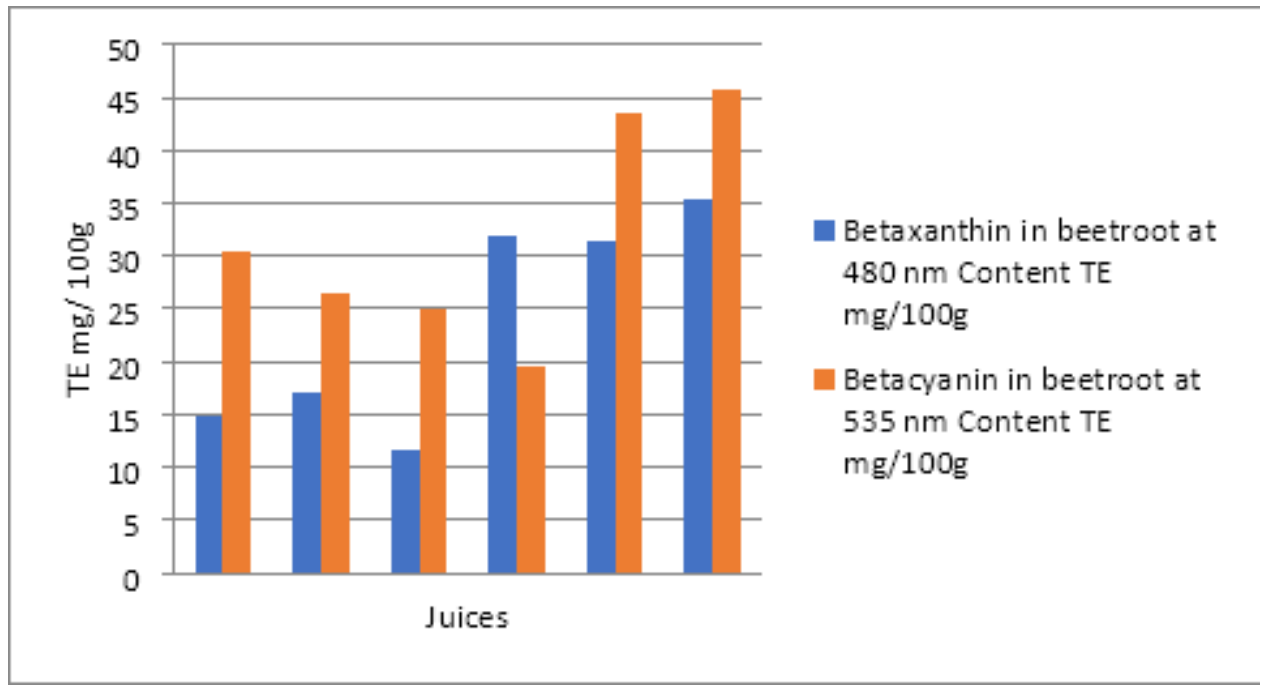

\section{Figure 14}

Content of antioxidants betaxanthin and betacyanin in beetroot juices at $480 \mathrm{~nm}$ and $535 \mathrm{~nm}$ respectively juice (1.Fresh beetroot juice to be fermented with Lactobacillus plantarum 2. Beetroot juice fermented with Lactobacillus plantarum 3. Fresh beetroot juice to be fermented with Lactobacillus acidophillus 4. Beetroot juice fermented with Lactobacillus acidophillus 5 . Fresh beetroot juice to be fermented with Lactobacillus delbreuckii 6 . Beetroot juice fermented with Lactobacillus delbreuckii )

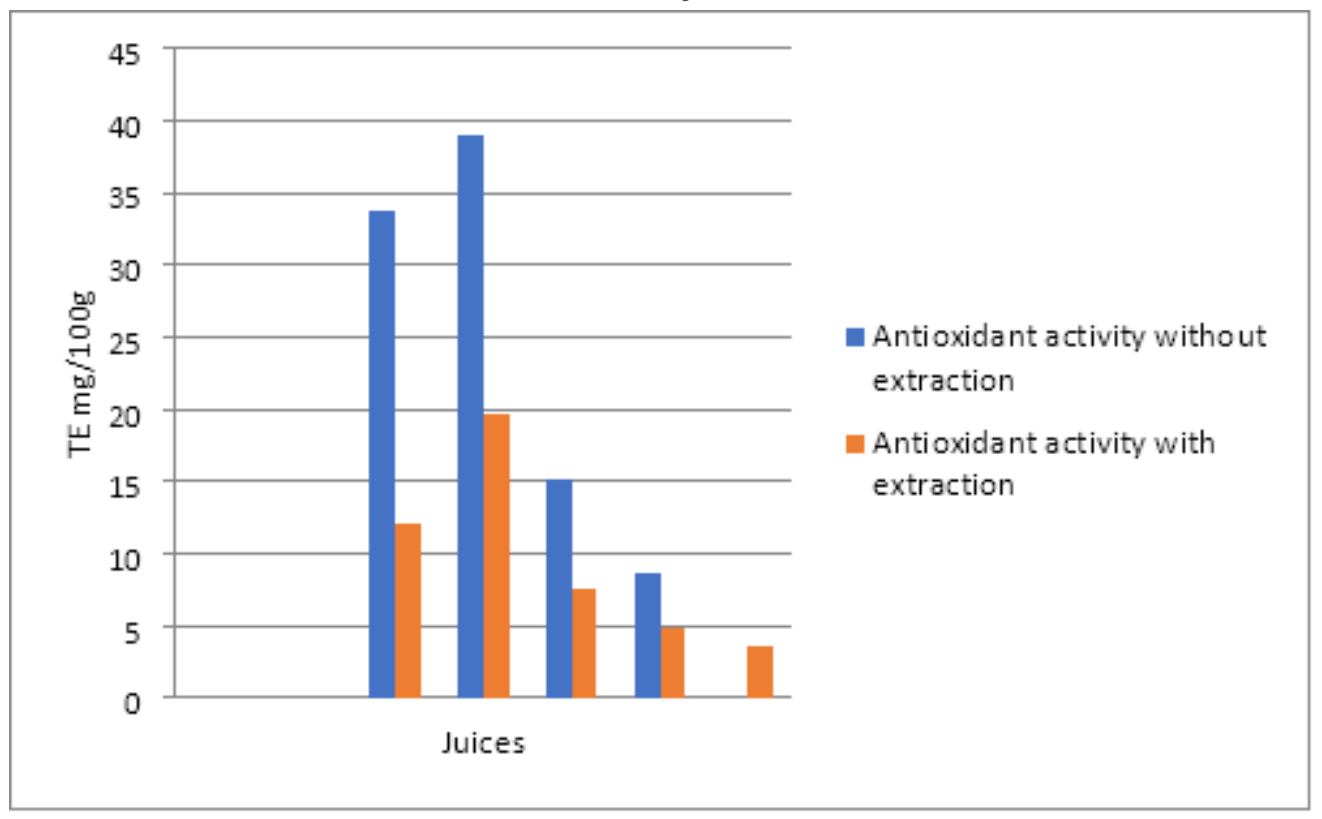

Figure 15

Antioxidant activity in carrot juice before extraction and after extracting by 70\% methanol (1. ABTS 2 . Fresh carrot juice 3. Pasteurized carrot juice 4. Fermented carrot juice with Lactobacillus plantarum 5. Fermented carrot juice with Lactobacillus acidophillus 6. Fermented carrot juice with Lactobacillus delbreuckii) 


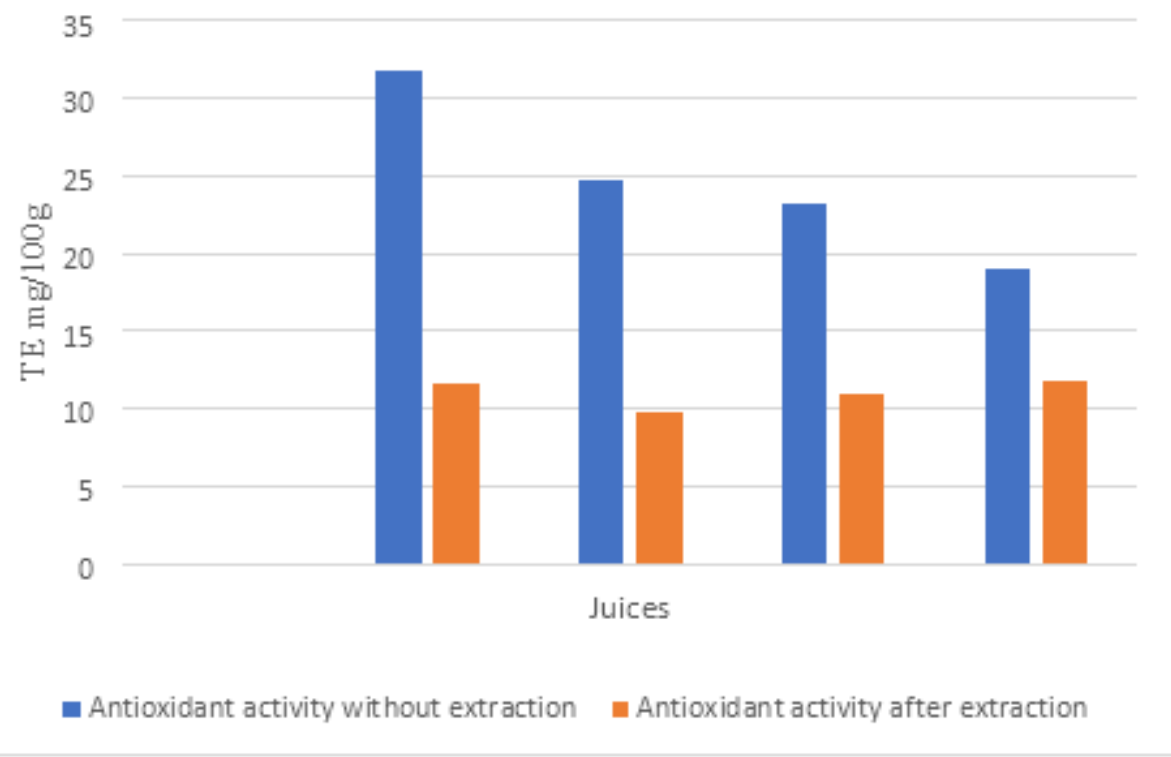

Figure 16

Comparison of antioxidant activity in fresh and fermented tomato juice before and after extraction with 70\% methanol (1. ABTS 2. Fresh tomato juice 3. Fermented tomato juice with Lactobacillus plantarum 4. Fremented tomato juice with Lactobacillus acidophillus 5. Fermented tomato juice with Lactobacillus delbreuckii )

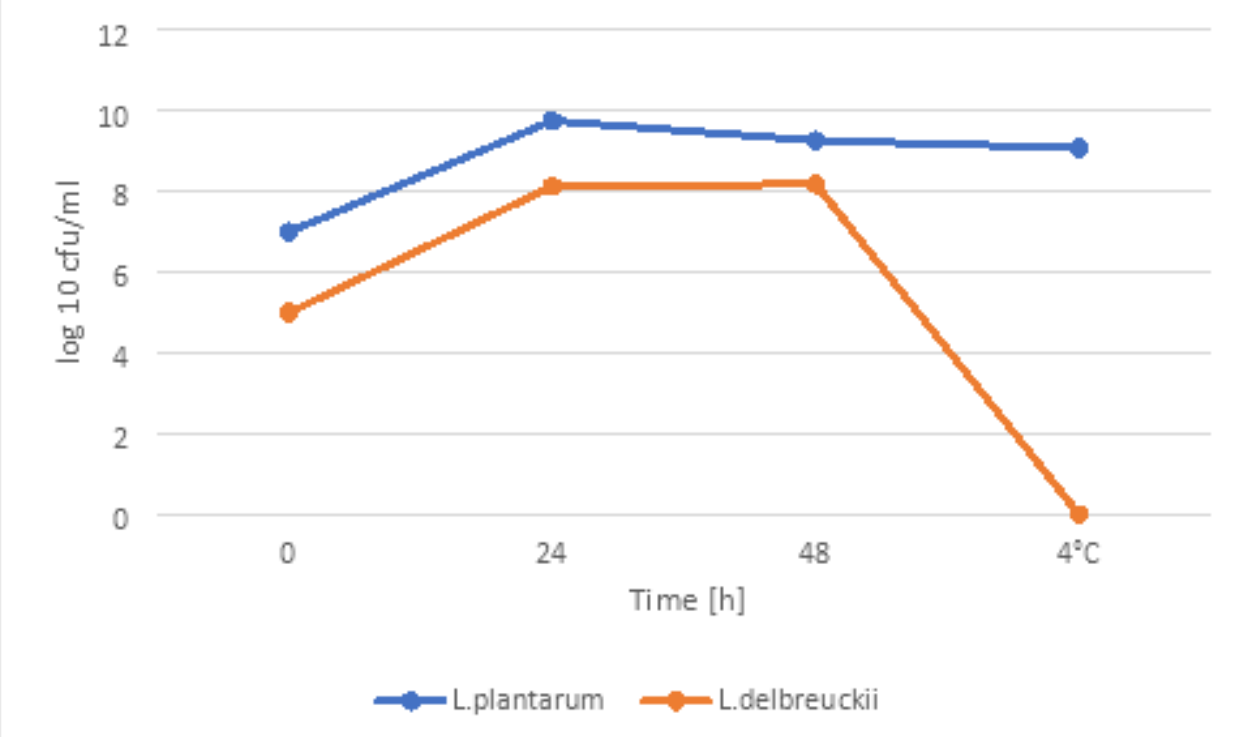

\section{Figure 17}

Comparison between the changes of the growth of two strains of bacteria in carrot juice 




Figure 18

Comparison between changes of the growth of two strains of bacteria in tomato juice

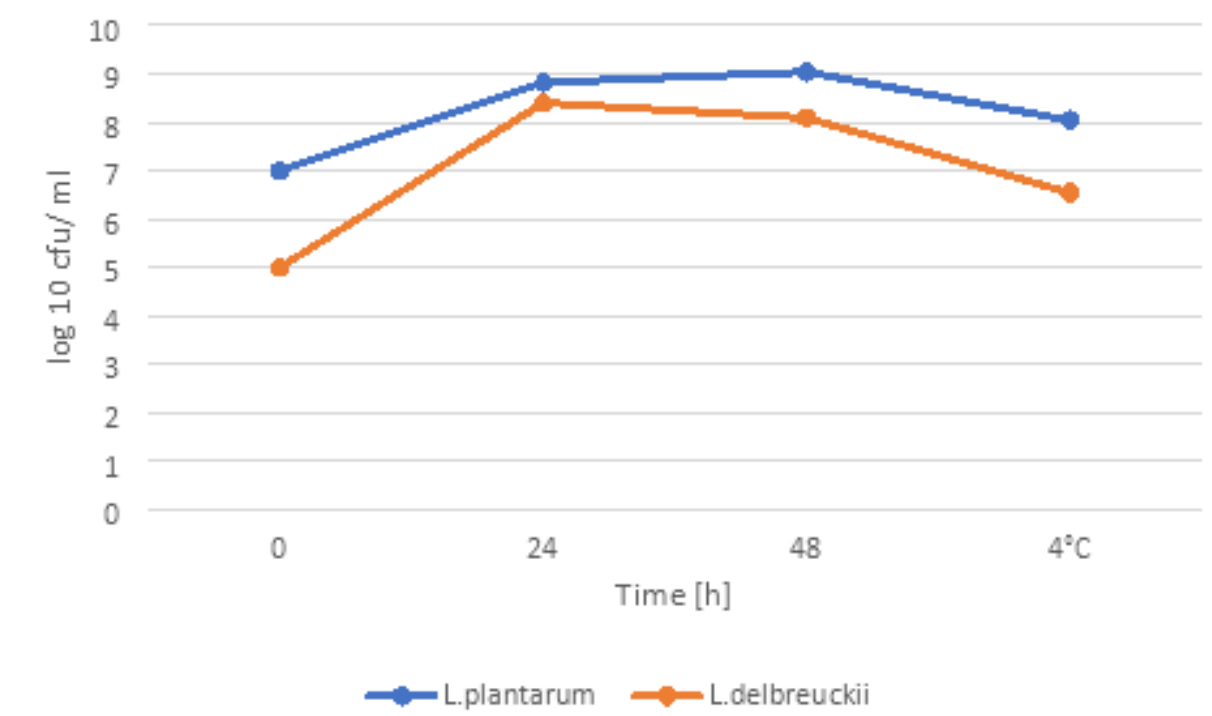

Figure 19

Comparison between changes of the growth of two strains of bacteria in beetroot juice 